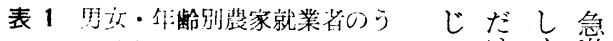

ち席業在とする者の制们つけく激経

(都府県合計) (监位\%) つで促な済

\begin{tabular}{|c|c|c|}
\hline 年: 精 & 男 & 女 \\
\hline $16 \sim 19$ & 45.9 & 34.5 \\
\hline $20 \sim 24$ & 56.0 & 29.8 \\
\hline $25 \sim 29$ & 50.5 & 13.3 \\
\hline $30 \sim 39$ & 44.0 & 9.2 \\
\hline $40 \sim 49$ & 40.3 & 7.9 \\
\hline $50 \sim 59$ & 29.6 & 5.5 \\
\hline $60 \sim 64$ & 18.2 & 4.3 \\
\hline 65以!: & 10.6 & 3.7 \\
\hline $\mathrm{at}$ & 38.5 & 12.3 \\
\hline
\end{tabular}

（洼）表 $1 ， 2$ と主『1960 年世界譨林業 センサスれ(表林省)の抽出集計結果 にうとつく。

あな進労の るくし動 高 が、つ力度 あつ流成 が なと出長き は
が
き そぎるは の流最就と 主出近職 ゔ 流のに離く は增お村第

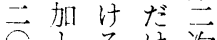
上交次 離で お 前う村なよ 後点は、くび ので、、第 傍 注そ在 系目の宅次

表 2 続柄別㕮家就業者のうち兼業 次す量兼部 主上する将の割合

莮き增化へ

（都府県台計）（单位\%） に筫大をの

\begin{tabular}{|c|c|c|}
\hline 続 柄 & 男 & 女 \\
\hline 世带主 (素)! & 30.7 & 6.0 \\
\hline 克こつぎ(妻) & 45.7 & 7.7 \\
\hline 资二用 (㚲) & 61.2 & 38.4 \\
\hline O 他 & 32.9 & 11.3 \\
\hline it & 37.5 & 12.2 \\
\hline
\end{tabular}

化報な業者る調長

の告っそ経のが整下こ 実畫たこ営女、艺にの あ的と娄莀 る変いい業 之化う方各

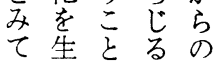

農
家
経
嫦
主
あ
あ
こ
ぎ
兼
業
华
問
題
の
考
察 態 | 調で上性他、およ の抽查以に化面農いう 若出結下を。そ業てな 干集果、多证折ま農 の計と筆く年は得守蒙 側 (1) 者の化経のま労 面に一无問な営劣す㨐 をに九昭題ど全勢顕力 明基六和をの省著兼 らう゚音投形あ台業 かき年六げでとなな化 に、世华加農っりつの し最界 三汗業き”て 急 、近農手る学厤部き激 その林にに衝の分たな こ農業人至力農補農進 に家七口っ構業う工行 頙直ン問て成離に間は 在柔サ題いを脱役の 化労不研了ゆ立所一 し力農究。が農っ得面 つ㗢家所

つ兼調で

あ業杰行 め、業て格高 、榓当は差度

に和国 1 け藏よ 至言豊おで憗い。 た年のびくのこ 度就表業静れ 家者をと層対 経の参つ主 済う照ぎり在 調ち远五 查兼九営歳業 方業杂辛帒々 に主年でまう 農它世をで形 外す世界ももで 所る界広更の 得者嵊沉ん農 はの㷊にで業 農割業捉お離 業合七方り脱 哲はンる、得妁 得約泪至た年 ほ割に主在粉 注によて宅的 拮達るい次に 垫充々る畐 る昭全表男方

皆

II

穷

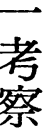




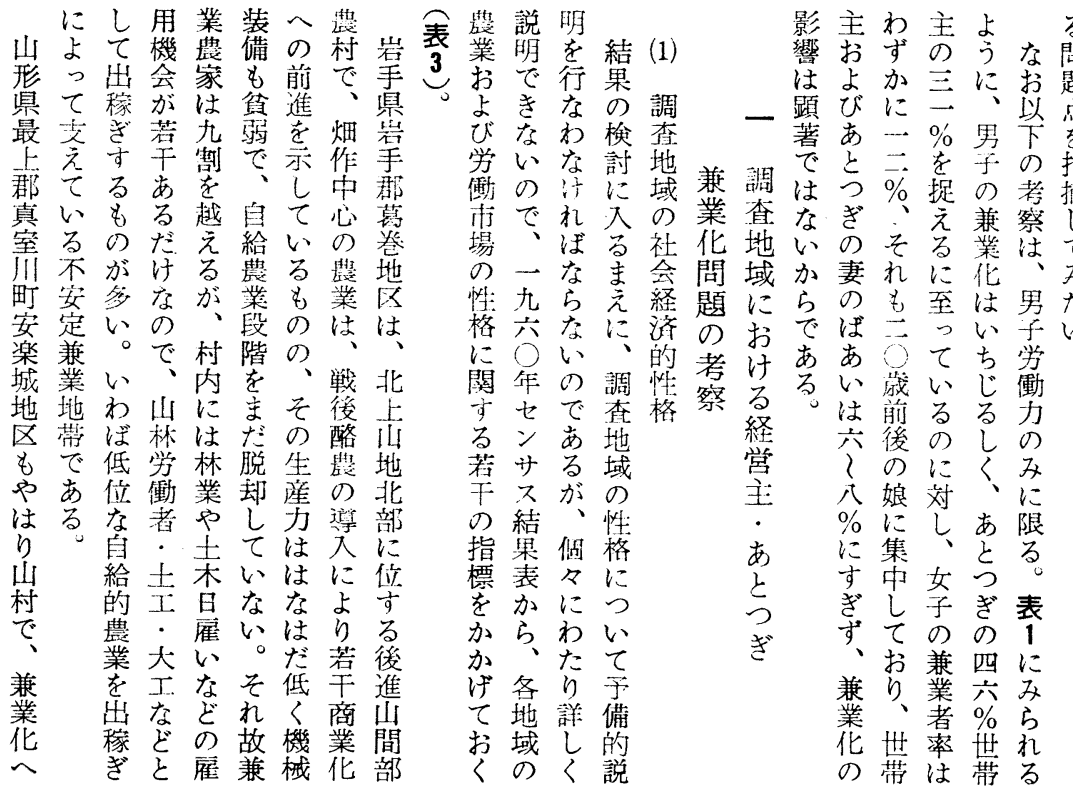

表 3 調峚地域の農業経営および学㗢市場の性格

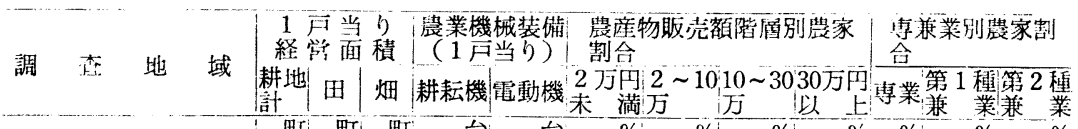

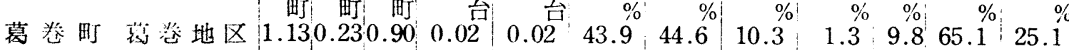

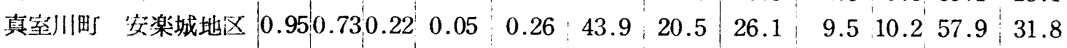

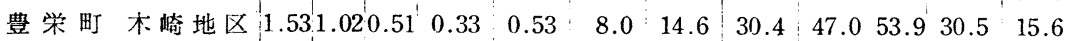

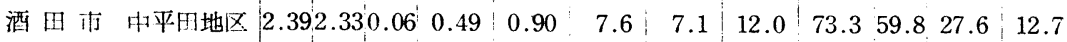

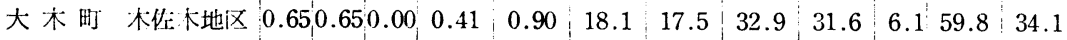

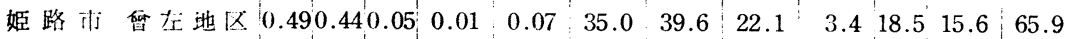

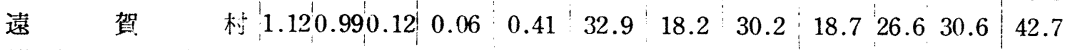

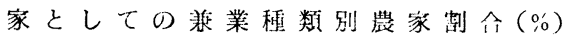

街 地域第 1 種兼業: 第 2 種兼業

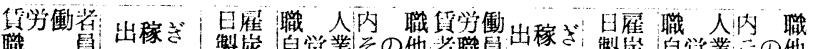

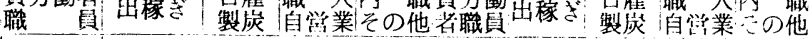

\begin{tabular}{|c|c|c|c|c|c|c|c|c|c|c|}
\hline 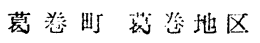 & 5.8 & 33.0 & 53.5 & 4.5 & 2.9 & 23.9 & 16.0 & 30.1 & 28.3 & \\
\hline 室川叮 安楽城地区 & 10.2 & 5.6 & 74.5 & 8.5 & 1.1 & 23.9 & $2.9^{\circ}$ & 53.7 & 18.1 & \\
\hline 町木崎地区 & 52.8 & 9.2 & 27.8 & 8.5 & 2.1 & 42.0 & 1.8 & 24.0 & 28.8 & \\
\hline 中平口地区 & 49.2 & 2.4 & 25.8 & 17.7 & 4.8 & 49.1 & - & 19.3 & 31.6 & \\
\hline 木仯: & 11.8 & 2.9 & 2.7 & 76.2 & 6.5 & 37.6 & 0.9 & 8.4 & 40.5 & \\
\hline 賭工 & 61.5 & - & 9.2 & 29.3 & - & 74.2 & - & 4.0 & 20.7 & \\
\hline 26 & 81.7 & - & 9.7 & 4.7 & 4.0 & 75.4 & - & 2.3 & 17.7 & \\
\hline
\end{tabular}

（注）1）『1960 年世界㖘林業センサス』による。

2）調查地域のうち酒田市では中平田・北平田の 2 地区を，姫路市では，合左・安公・余部の 3 地区 を誮查したが，ととでは中平田および留吉のみをそれでれの代表としてかかげた。 


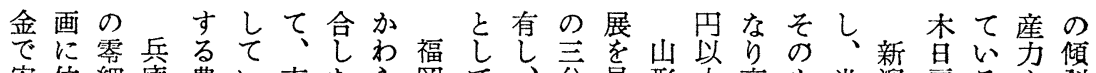
安位細庫農い東た方岡て、分自形上高も米潟㕍るも斜 定し経県家る北集ず県の貶のた県がくの作県い。葛の し、営姫㤎。酒約、志性売一庄酒約、でに北なま巻強 た富で路多な田的区㵔格額が芮半機は野蒲を゙ない 兼士あ市いお地高当郡を三三平市数械蒲菜原の兼り低 業製るのた表域生四大示○町野中近体原. 郡就業高生

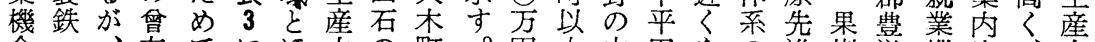

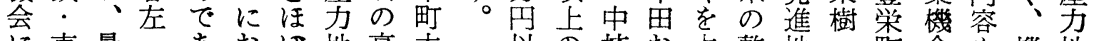

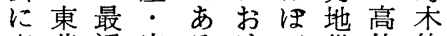
恵芝近安る讨匹带位佐 まを発室。る敵での木

れ注展塜守米地

てじの余業るり作区

おめ心部曹西、り性

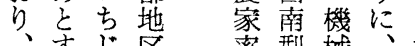

兼るる注率型械現六.

業大し

者. 心農

の中西業

大企播そ

半業磨の

がへ重名

職の西の

員比業

. 較地平

积的带均

労高の四

低位備金五 心生、叹反 の産農益と

は另家の

地带㳗多雾 草ののイ細 加一実草経 工 典貿栽営 を型に培に

㗢兵一区

以の核お占整地. 町会も機地 上大地よめ備域養木积、械带 が経带び、もを豚崎多低装で 七営を北専進構な地い位借あ 割で構平業み成ど区たな、る

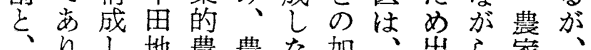

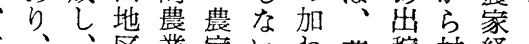

安、、区業蒙心わ蒲稼村経々 定全平は地経がっ原き内済の し農均、带済、た平はにの農 た蒙経篗のに総多野少国点業 専の営後面お体角野な有では 業半它飛目いと経の㮏和米 的分至躍壳て営北。学若作 高分町的保もて楖部働午中 位耕をにっ販ので海・の心 生引越生て壳生古岸炭進で 産ん充産分額産る。烧歩古

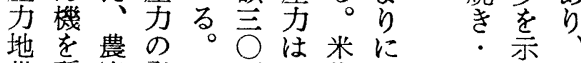
带所家発方加作位土し生

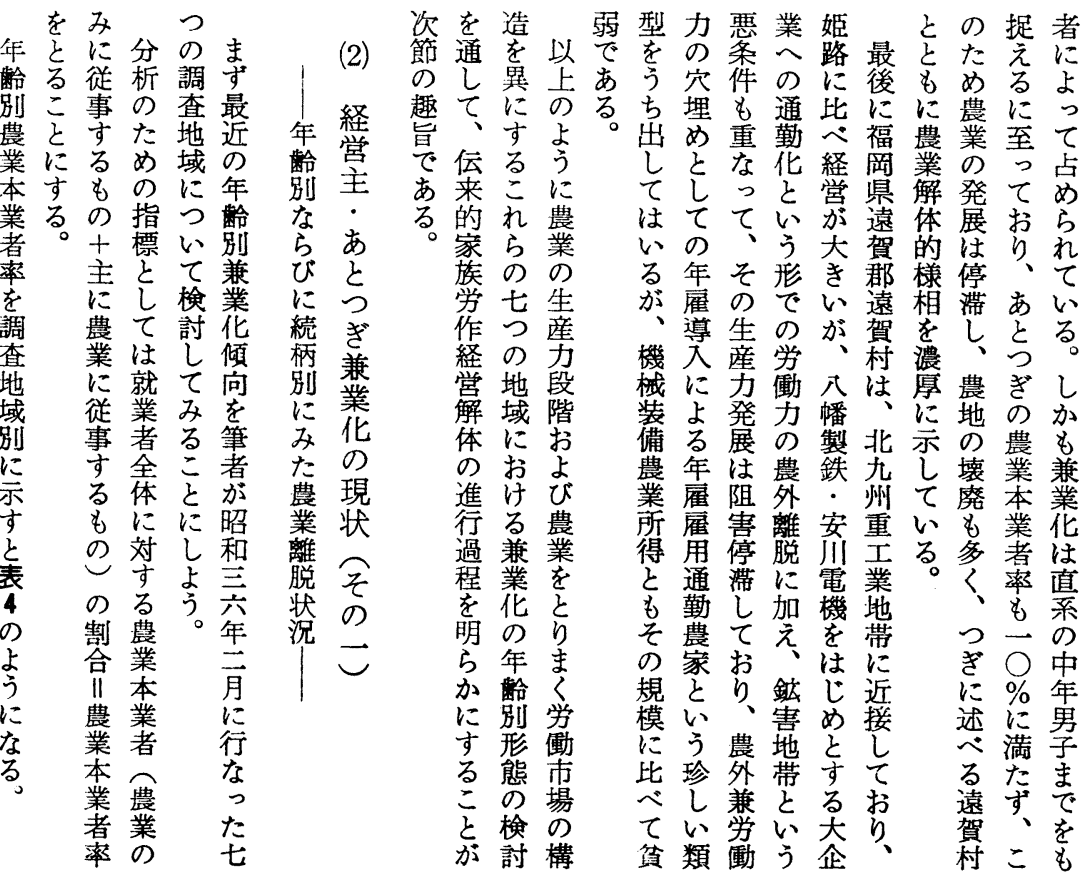




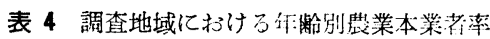

\begin{tabular}{|c|c|c|c|c|c|c|c|c|c|}
\hline & 葛 & & 真室川 & 目 & 豊栄 & $\left(\begin{array}{ll}\text { 姫 } & \text { 路 } \\
\text { I, } & \text { II })\end{array}\right.$ & $\begin{array}{l}\text { 姫路 } \\
\text { (III) }\end{array}$ & 迋賀 & 大末 \\
\hline $15 \sim 29$ 藏 & 51.0 & $30.4)$ & $54.9(31.7)$ & $68.7(65.1)$ & 62.4 & 13.0 & 4.6 & 36.5 & \\
\hline (うち世带主・あとつぎ) & 63.9 & $38.1)$ & $57.9(38.8)$ & $78.2(72.8)$ & 80.3 & 14.5 & 4.4 & 37.8 & \\
\hline $30 \sim 44$ 藏 & 65.0 & 42.7) & $71.4(39.2)$ & $82.0(76.5)$ & 81.8 & 25.4 & 7.7 & 45.6 & 1 \\
\hline 45 59瓷 & 76.60 & $63.3)$ & $76.9(53.8)$ & $82.4(78.1)$ & 85.3 & 50.2 & 33.7 & 61.1 & \\
\hline 60 歳以上 & 82.3( & 72.9) & $91.5(80.0)$ & $94.8(91.5)$ & 95.6 & 90.7 & 91.6 & 85.8 & \\
\hline 計 & 65.1( & $47.1)$ & $68.7(43.9)$ & $78.7(74.4)$ & 76.9 & 37.6 & 24.5 & 51.3 & \\
\hline
\end{tabular}

(注) 1)（）内は農業專業者率

2）姫路 I，IIは姫路市睤左・安空地区で，姫路而は余部地区をあらわす。

生の市地 ちいのしをが前ぞ年在低高な向力い業

産市で場域こじてはてほ直後の層李卡さがとにう承い 力なあのののるで、いと系のも无る傾おら異い形がず 専わる構農よしあ五るん女高のは。向よ各なちで低れ 業ちこ造業ういり旮。ぞ子率で、もにび年るじのまの 地、を的生な。、歳地受々をは地っはそ龄とる農っ地 带酒は差産差賈域忊同示な域々、の層こし業て域 で田説異力異く芐差てじしく差も顕若にろい離おで は・明に段がにの堆いくて、は六著年おはこ脱りも

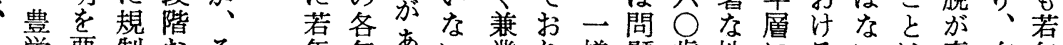
各栄要制おそ年年あい業り様題歳地にるいは青在年 年なしさよれ層齢らこ化、にに以域向本。全壮宅層

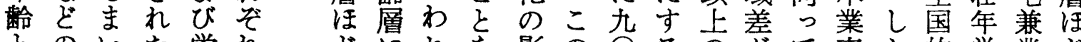

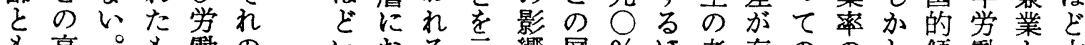

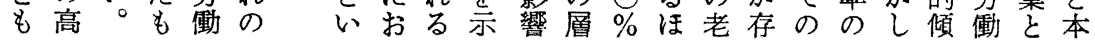

帯的 4 合内表れ殊酒な示は行山路るち本

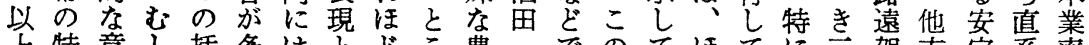

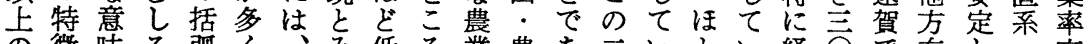

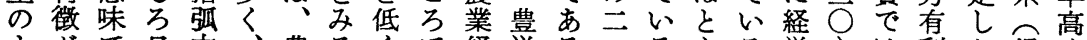
よがで旦、農るくで経栄るつるんる営〉は利た経く、 う示の雇の農闗仝営に。の。ぞ余の四なな年営

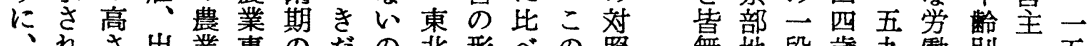
れさ出業専のだの北形への照無地段歳九働別・五 もてに稼専業臨ろはの態本う的に区との歳市農あ?

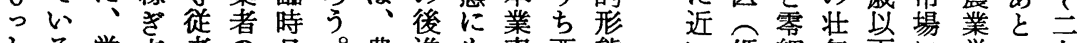
々る労者者の旦。農進も率西態心姫細年卡に労う旮

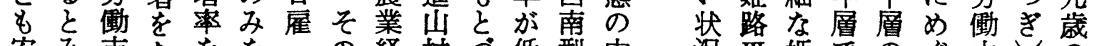

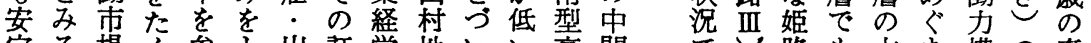
定る場々参之出証営地いい䯩間で䈃も本ま構の青 しへにさ盟れ稼拠の带ての位に、のの本業れ成み年

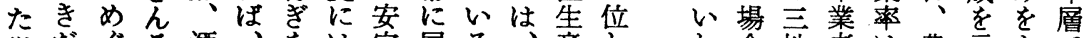

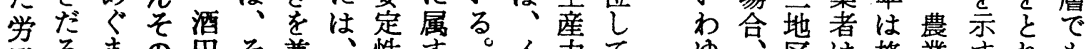

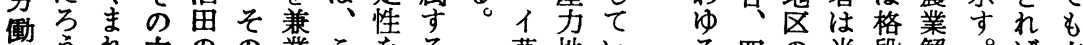
力うれ内のの業こをる草地い 力。なに場割之れ示葛加带る 構い包合合尔ら卷巻のの

成低みとはるのよ童一が

を生込比格不地り真業典大

示産ん較段安域は室型木

て 吕た本。低な農業の 組を莫

い安業く農業の本合す巻

る定承な業本番

の農の る者業し率

は業名 つの者さが

わ大

酒

衰割の者され 特架寚

る四の半段解

農四う分に体

業歳ちに低的

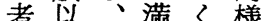
者輔も満く様 \%を越 态のっな経の 近罜とい 危孛字。亭方值お 危子機厝兼虫占值お を業業

端本 化 的業のあいこの 八分 $\%$ に者進る姫ふう 


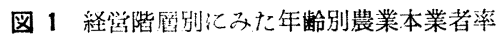

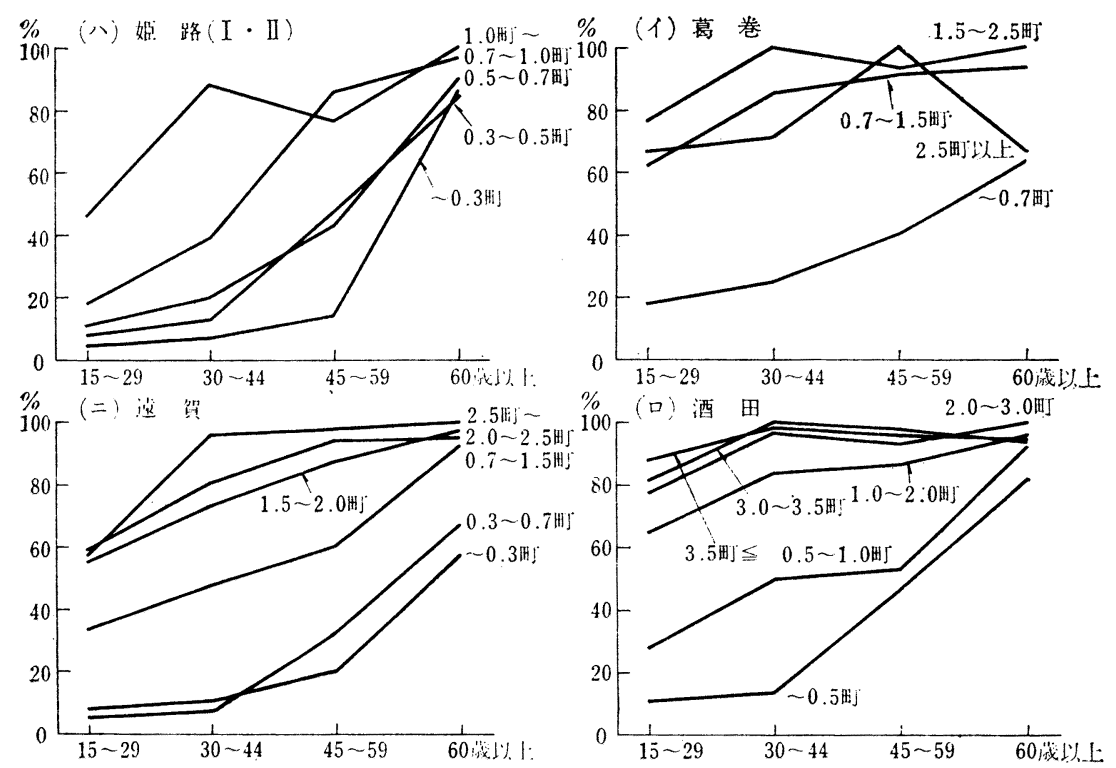

むとる層が辺問の、模一つ合合に就遠労不田

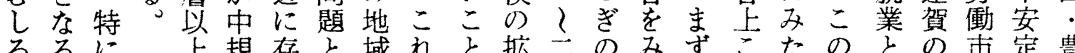

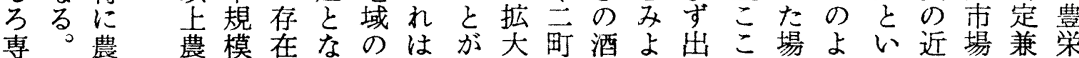
業図業芜以しっ特経注に層思う稼で合うう郊に業? 者 2 専の上なて徴営目伴よよ労はにな形通め地大 率お業本のいいをのさうりり図㗢葛は各で勤ぐ带木 がよ者業不こる表大れ年もそ1に巻ど地、兼までな 高びの率安のこ現きる龄むれのよ・の域労業れあど い図みを定山と专い。別し注( (1) 酒よに㗢地なるの の 3 比農村をるこ本ろと过て田うお力率い葛生 だにと較業地示もと業高低葛そ・なけ構でた巻産

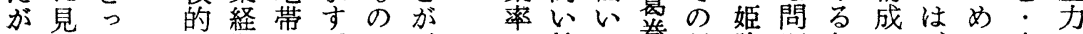
、䯩営で。で、の值と巻低路題年の滇の 中れ酒水をはたあ必傾をは里生高点龄不四不室高 ·る田準支、たり导向示、本産・学別安○安川い

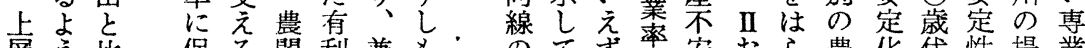

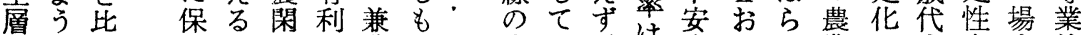
経に較持唯期な業農上い、は定よん業架まを合的 営、等せ二の依業方る一一農びで離明で内は経 の下れしの出つ存の 専層ばめ支稼安の安 業農こて柱ぎ定要定 者家の いで・ し請性 率で点るあ臨たがを がははだる時兼全意 酒葛さけこ日業階味 田巻らなと雇機層し にのにの吕い会をな お方明で、の蒲蔽い 计茫瞭 あ中み近うこ へが・五業遠い脱瞭の包、営 の、五吾を賀る傾に直し本地 ス酒町支に支向認系て業曼 ラ田以旮若乃をめ基お率で イの上昆て察う、ら幹りの ド盧歳いを加され労、高生 がうでをる限。らた㗢まさ産 明には除葛る紙に。力たの力 瞙経酒け巻。面階 の姫背の で営田ばの の層農路後低 な規の、場、都別外・にい 

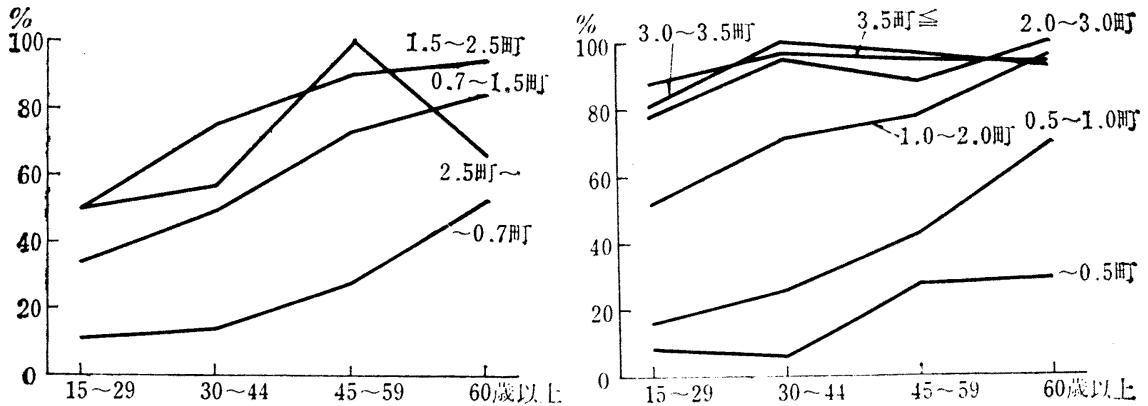

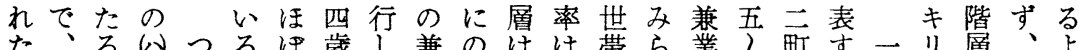

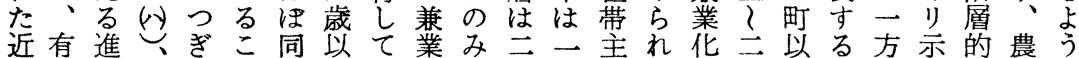
郊利行兼にとし市お化限町 ○あずに九上酒、問業な 地なは兼姫が水のり淀以 $\bigcirc$ よ藏層思安て題経顕 带兼葛羓路注準本、葛さ市％う二るを注で定いで営著 の業巻の华に業五巻れのにぎ五本除次は大るあのな

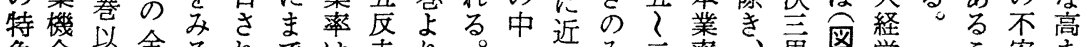

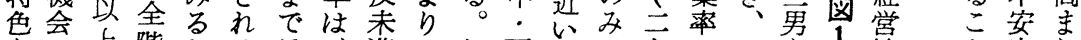

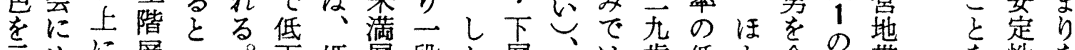

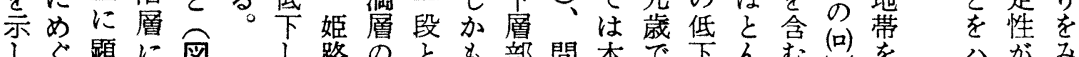

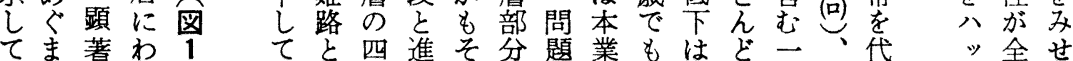

のにを打業とのは姫経のと家よ下七じ大い㗢男い 本はうけ率だな高い路遠営量考のうの反る 業三吕るはがる年っに賀々貿年な青々三々ことはが

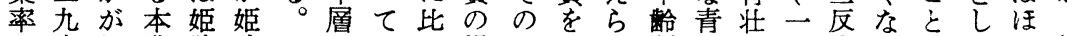

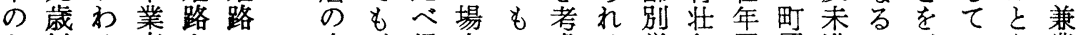
か以せ率よに本、経合の虑る労年層層満に示のん業 な市るのり比業上営ものし。働層とでで従し価ぞ化 りの。傾\& ぇ の本他斜さ兼 低業方はら業 下率上かに化 が落え低の み低農っく、整 らく家て、更 れ、でゆ四の

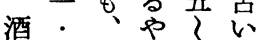
西五二方五遠 に酒賀 比三五な歳の さ・町り層場 不五以、以合 安町上兼下 定層の業の中 化最化严市 へは上のう層 の四層一のの き四の段年年 さ歳ばの齱粭 乙以あ進層別 率層面ほ再ただ妿のはのい、値農の 低農積 下家茷同合こ成外にのる五業㕹にっ ものはしを就顕傾や杂化失従と 、本るよ緊こ層、業著斜少歳のし事も 一業かう迫のの三傾ながな以進たせ進

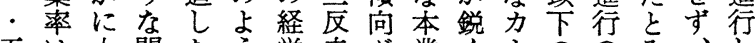
五は大問たう営未が業く、ののみ、し 町さき題問な規満現率、ブ三到ら農て 以市点題兼模層状の四は方達れ業い 下が遠がと業ののの断五、の点るはる のに賀指し化大形ま層歳漸年を老、㤩 中加で摘てのきにま的以次龄暗人一质 下なは提進さ近続低上右層示々般未

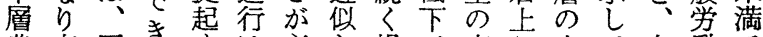
農高同き过は必場が高门本て女㗢で 蒙く芯年る、要て合認老の業い子市は

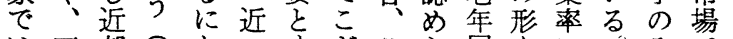

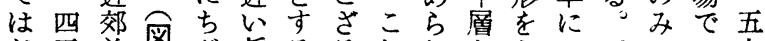

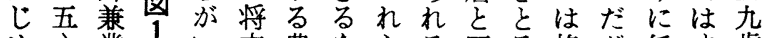
め)業のい来農をらる四る格が任す歳 て五地息に業え中。四蒫経さで以 顕九帯因い農労な層こ歳特が営れに市 著歳と。業衝い農の以に生のて労の 

兼菜加い图家 $の$ 町上現莱 哏もる 4 み、限方農 家そこし: を姫階れ家 のれと - 亡路層るの

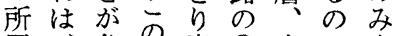
属、分層出 $\bigcirc$ 市はを す現加畨し、な当と る在る吕て七わ然っ 経のす作〉ち先て 営兼?应二葛子

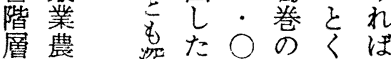
農家深鬥○に 家の刻あ洛年 全みない遠七調龆 体の震に賀々查别

の問業もの一地本

問題労っ—. 域業

題で働之・五に京

性は力五町お。

をな の顕市、讨こ

示く再著二酒る。

し、編な・田直傾

乙本成形 $\bigcirc$ 亲斜

W来問を町一労が

るは題之勫・働さ

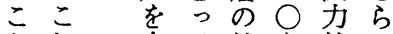

之市て兼〉兼に

にら包お業三業激
るてに 労速核い下時といこは お対先㗢な学う層的、以るれっ りすに力農な形の不そ上。らき 、る示構業军兼安れの 專ら こそし成離べ業定はよ 業み のれたの脱きっ化兼安う的せ 傾以諸不方直て、業定に規て 斜下园安、系進近へ兼、模い がのて定農青行郊の業最のる 激二は化業壮し地傾に近哏 しつ、劣経年つ带斜め嫁近 けのこ生営労つに市な郊 れ年れぜそ働あお生まけけ地 ば粭はしの力る汀産れるる带 激層年めをっるる兼浸て しの粭つの若そ常の心業蝕は W顕別つのいし勤高後化 程著本あ再経て兼い進の 問な業る編営そ業専山准 題断率。成主の化業村行 は廨に 梁的打 刻低け 然び層経に地

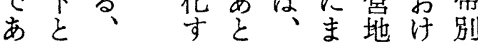
ると四るる農市带る階 之て五文き業及に全層 判表 歳 断わ以 ささ上 れ 層

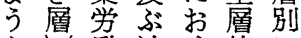
な働波计的に 農のの疋るなみ 業急中と 中臨る

図 4 兼業農家にわける経営陼層別農業本業者率
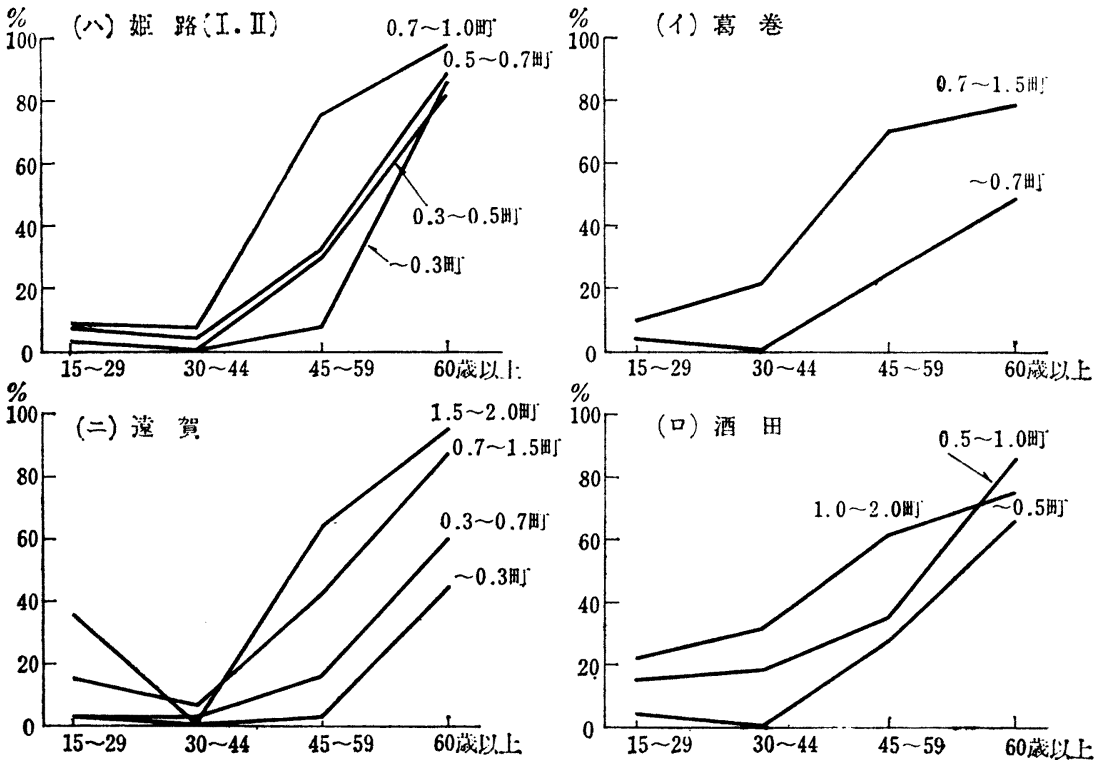
うい退了の層地わに

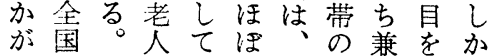
え農でし完六兼業移し る家 あま全○業化しな 之にりっな歳最のてが $こ \checkmark て$ 脱以下進いら ろい農い農上層行くこ でて業る化之農のとれ の 学: 四家最、ら 図経働こW五にも問の 5 営 $の$ 小特 $心$ 題兼 、㷇の層吕五にちの業

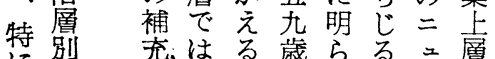

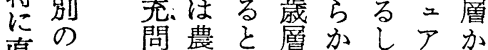
直年題業豊䔬ないンら 労粭はの業あるこス

学别実主学いうのはさ

力 本

の 策

みの

を傾

之斜

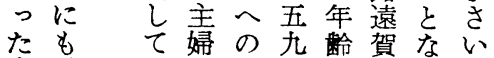
実—し淿転歳層なるる。兼

線学

分は
質要働だに層異ら 的なのに、でなに に担老移本はつ経 は当人行業、た営 解 者女し率姫名の 消は子、の路の小 ひ市下の近す市 て隠完層断郊な䡒
よのる問兼幹がた層て家注 う進そ加題業学専労のい之目 行れら が型働業㗢専るいせ 吕故で、へ力の年業之うね

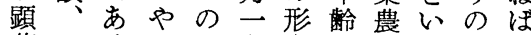
著一るが移人をに家うはな で般かて行しと達の夕、ら あにらこがかっし大イ世な る農でれ尒確てて部プ帯い 中業あら想保い心分に主。 層労るのさでるなはよがな で㗢い専れきのい、農ぜ 力業るなはと世て業な 之構型。以、以带主にら く成農そ時フう主に従直 に家れ期ア夕六構事系 以不に故にミイみ成し兼 ち安も現位リプがさ、業 じ定当在しイに農れあ化 る化然のて . 属業てとの しは起兼いサしにおう上 いるこ洋るイて従りぎ限 、直っ患たクい事、方階 と采て家め儿るし二農層

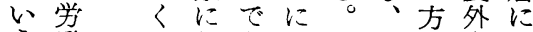

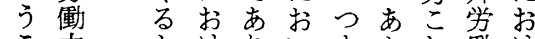
こ力 $力$ り 之の 考る、て りっとにる 落兼当将男こぎ同従兼 で業ら面来子れは一事業 き化れの基ら牛階し農
要間化とた故先す○年を

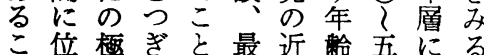

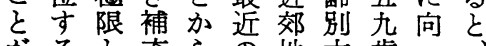

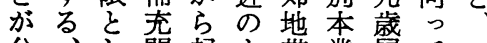
分、乙問起上帯業殿て一 加いて題こうと率にの. るわ直は注同のま傾五 ほ系てて若し傾で斜町 二労上くい上斜及古以

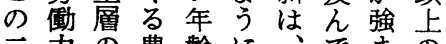
三力の農龄に、でまの つが安業層補五しる安 の豊定経々充九まが定 多業儿営々問煘口尃 多㕺自のに題少い最並 に離立問とをでる層赤 なれ経題う超はたの潮 りて営越加め三次

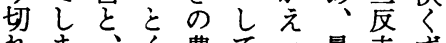
れま農て另最未す なっ最に外して初満れ いた下そ就まゆ急で出 中脱層の職っる角は主 間農に中前てや度 層型お心激心加の脱下 の経讨をる。低農層 問営るなく。市化 題忘兼亦なるり、杂主若
図 5 全国都俯県農家の経営隋層別 農業本業者率

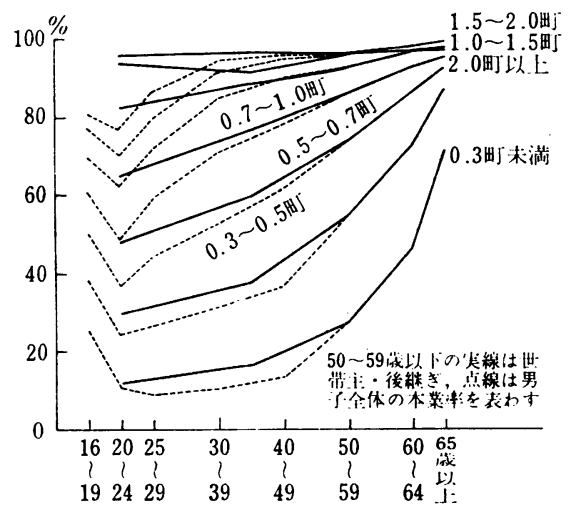

（注）『1960 年世界農林業センサス農家調查報告 昰—抽出集計 (1)-」1963 年,より 作成。 


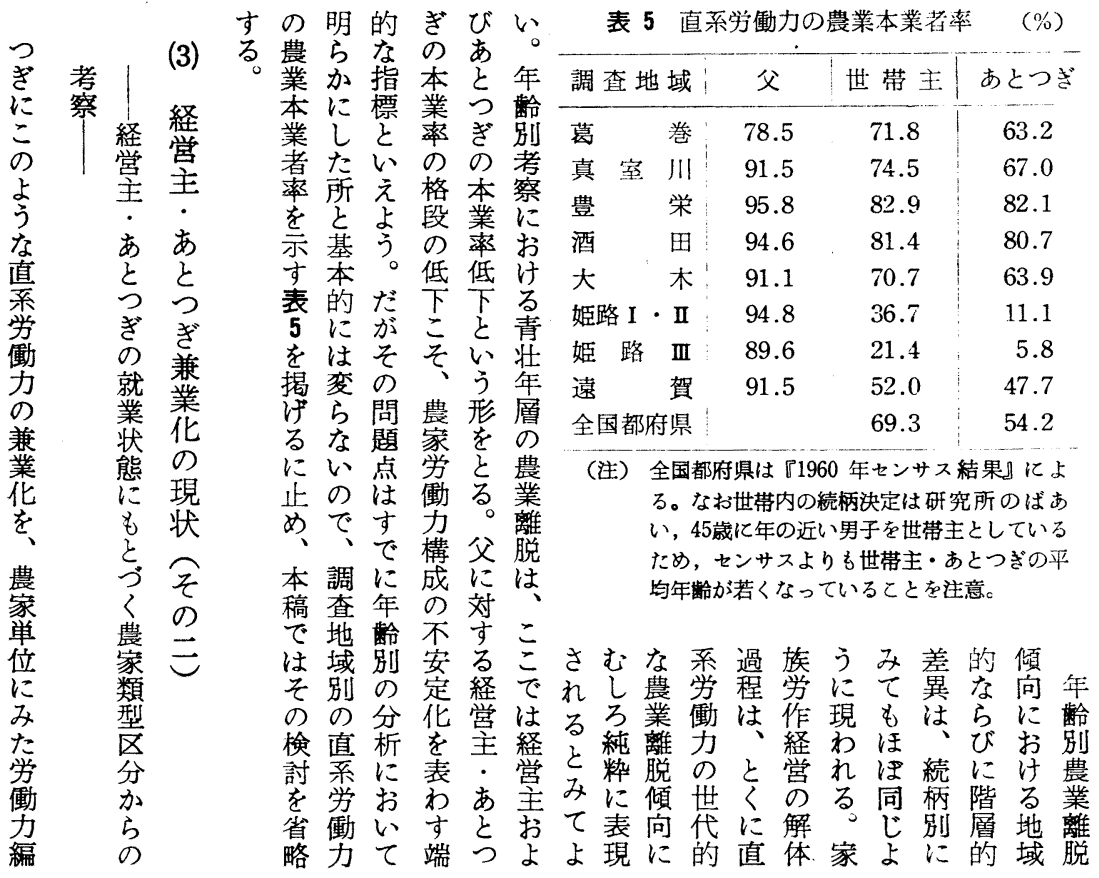

的もの経たた働

所た注あ重よ営こ問力气 得も远まな解よと補ら との い意直体うな充で 傍で従さ義采過なら問兼 系あ来に学程值ず題業 業た専比持働を系、を化 者乞兼へう力直労 III 生の のと業てとの接㔣でみ進 所、は、補照力は出行 得お分るえ充射のそすが まよは管混け基 でびはかる問す就れの梁筒た基 含、次にう題る業がは刻いさ问法

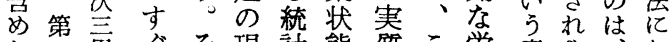
た男ぐそ現計態臀こ労意や尔お 農種卢れれ状的に的の働味す専け 外兼娘てがな指よに内力仿く業る 啠業ない通ら標る解 II 構弱、型目 得とぞる常び農消の成

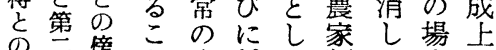
大種榜々專将て類た合の 小兼世は兼来、型こで問 に業帯 心業をま区と題 よと買う区確た分にI あ業言味

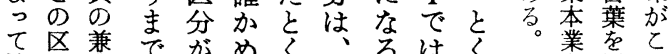
て区兼 決分業 め肪学を持るに家 れ農含 W注概め先觉艻基

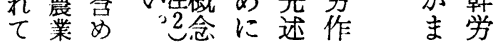
な直々立 る系う農 加全京

浮を 1 る来聚ま型者 は専自号 得兼京 る 区

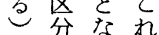

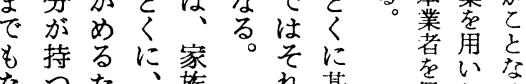

楅た方。 尃あと
III

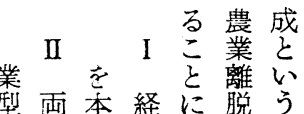

者者業営なは観 とのと主る、点 女 5 专。家妿 農方るあす族ら 業息々な労上 少人立つわ作り 離型注ぎ れ ん豊概み 農占に括る 業㐫農的こ はと業にと

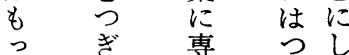
ぱ热ぎ ら があ のう 辛主当当経 兼は営 老業少 形主 に従省態市 㶵事京分交 


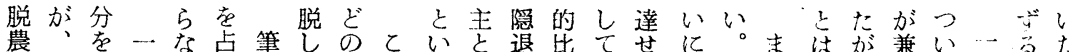

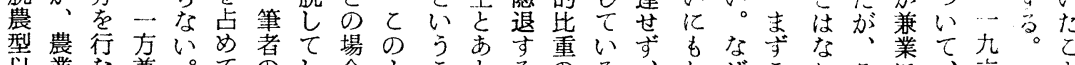

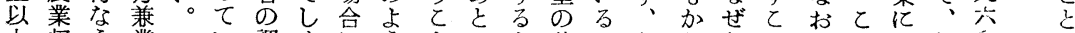

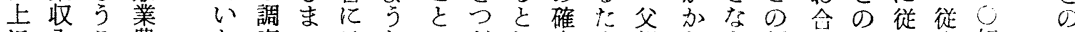

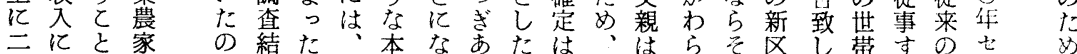

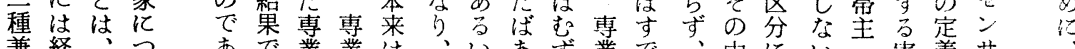

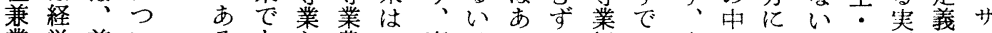
業営兼いる。青農吕直はいか経に家にお。开質沉 の陵 業て 比層化方

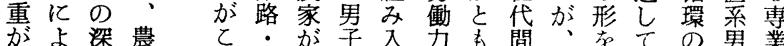

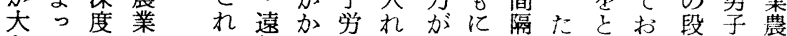
きてをを賀な㗢る一就をとっり階労家

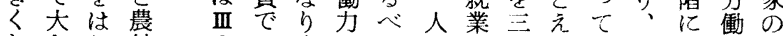

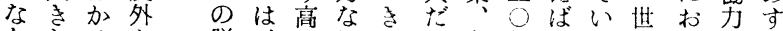

りなると脱、心しケ市年一る带い三心゙ 、開指 の 中き栖収 層方紊合

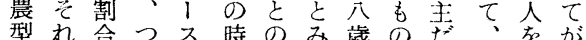
にがでまの期一て少が汀あ農 I

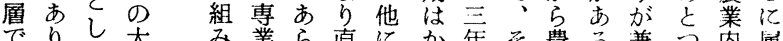

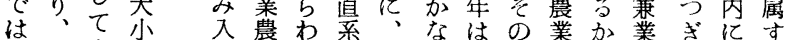

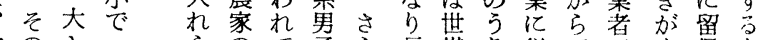

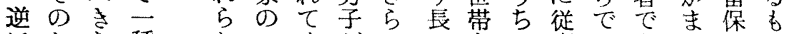
にたな種机一くがい主一事ああげすの 脱め意・ な五る農近しの七し方る学ると

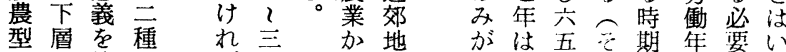
ので持のばの常就世歳のに龄が元 過はつ区 離 な

ま的上で筆 專齐用㑛 ぎ業専い行 中農業与京 心家農れ视 の 九家 た 新・音新 L $\equiv$ L 专 小\%・文 区 只六専 分 の在 の業卡 拿方少分方 b) c 前明飞全 記 ら傍国 の加采㹮違 江親府认 類さの県架
力 農

の業表

高本 6

い業は

先棑々補域

進のの遗つそ

豊比地のいの 業較域々 1 分 地に別 2 場 带お結 の合仕 W果説と方 豊てを明では 栄見示奇は 酒方堭基九 酒れた然基六 田たも注 ・地の乙年 大域でたセ 木的あ デン に盖る。名希 自己こ㤎結 立ほれ造果 型ほをた整 の並自め理 此行る 荐の 重しと、 異含 最、年皇。 生龄調 高産別 小查
参つ農必農一農成表 $\bigcirc$ 把るの

照の家要だ家一家し马年握問農し

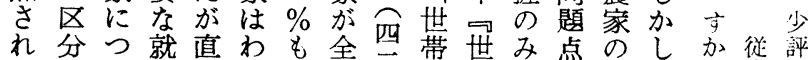
たけい業愻ずあ体面主界かの区な沽来価 注がて動労かりの貝々農ら一分が 可可向働に、五をあ林でっけら摞区い

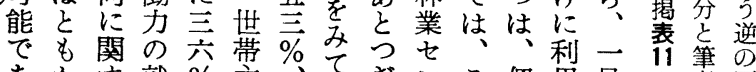

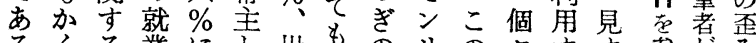

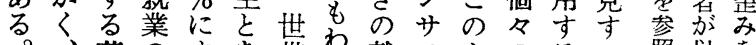
若のすあ带か就稀よのるこ照以范

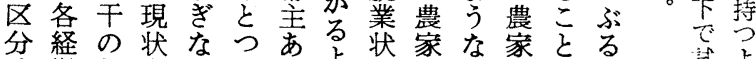

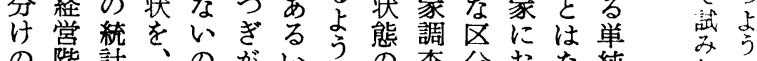
の階計、のがいうの査分おな純たに

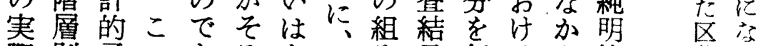
際別予のあろあ一み果行るな快分范 的の测概るつと六合報な直かな 方農を念。てう裔わ告え采むこ

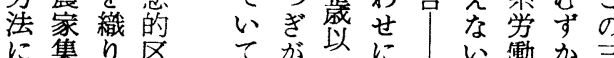

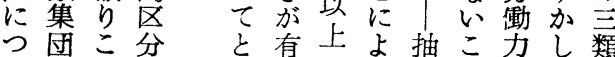
いにむに文業のる出とのい型 てつなつに者あ農集で就。も 補ては将業な゙と家(計あ業ここる の遗は個たる者いき農な型の一態に最を 2 の を三のにるがの構三六状困実
家:

辏 上

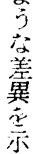




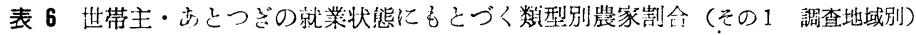

(單位 \%)

\begin{tabular}{|c|c|c|c|c|c|c|c|c|c|c|c|}
\hline & & 葛 巻 & 点室川 & 豊栄 & 酒田 & 大木 & 姫 I 路 & 姫路 III & 迩 驾 & $\begin{array}{l}\text { (遠賀) } \\
\text { (町末満) }\end{array}$ & 舍园 \\
\hline I & 自立型 & $\begin{array}{l}44.4 \\
{[9.8]}\end{array}$ & $\begin{array}{c}46.1 \\
{[10.2]}\end{array}$ & 61.3 & 62.1 & 49.8 & 10.8 & 1.4 & 26.3 & 4.4 & 33.2 \\
\hline II & 兼業型 & $\begin{array}{c}24.7 \\
{[65.1]}\end{array}$ & $\begin{array}{c}27.1 \\
{[57.9]}\end{array}$ & 21.9 & 19.2 & 19.6 & 25.1 & 18.2 & 23.5 & 14.8 & 31.2 \\
\hline III & 脱農型 & $\begin{array}{c}30.9 \\
{[25.1]}\end{array}$ & $\begin{array}{c}26.8 \\
{[31.8]}\end{array}$ & 16.8 & 18.7 & 30.6 & 64.1 & 80.4 & 50.2 & 80.8 & $\begin{array}{l}34.1 \\
{[\xi \omega \text { 他 }} \\
1.6]\end{array}$ \\
\hline
\end{tabular}

（这） 葛巻, 真室川の[ ] 内は 60 年センサスにおける専兼業農家割合を示す。上よりそれぞれ尃業・第 一種兼業・第二種兼業。

能くなとい段経は不業業自は而きは安離型な近こ性草が皆なく、 た酒しう。の主す定脱も型々遠比自郊和も加、自い兼 け田は点もそので化に少はれ賀重型地とを立こ竞へ業 の・五でっれ農にもみなほほのを型带対ゔ兼れ型大型 中豊反はとで業あ、らくと圧而点带盟い業は架木お . 栄々、を㐫離とこれなん倒町め少危的てと先少でよ

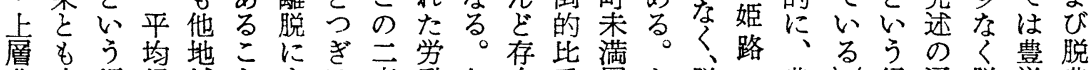
農态姫経域々ま法者働年在重層々脱: 農过経通脱栄農 家分路営とをでもの力龄せをのく農遠業営り農・型 を比でがの示進と場構別ず示場に型賀解農型酒は

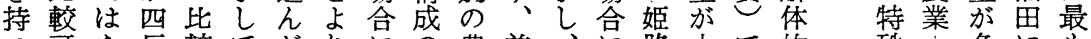
つ可な反較てたりにの農兼、に路大で的殊十多にも

外び兼るびの述へ産たと業

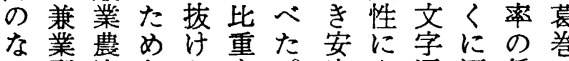
に型家とたを。定も通酒低 ものを思高もそ的とり田さ真 の比ほわさ高し兼うのにに室 で重浑れはめて業く自お比川 もの同る、てこ機農立けべな な大水。こいの会業経る、ど いき準とれる同の内営よ自の さでもに。艺への立後 こし冬も事しの比な型進 そか人期っ情さ労重経の山 な、崖と古に働を営比間 まW農焼它脱よ力表の重農 さ、業き、農るのわ合は業 に二哲兼真化名緊し理意地 得業室の自縛て性外域 農ら吕と川不的といとにで 業のらいに徹専農る高大は 経地みうお底業業の所き 営域た特けの化所で得い専 のには殊る条で得はにが兼 不おあ形兼件あのなる、業 安汁態業とる貧くっそ区 定る、加型なこ困、てれ分 性自姫加のりをを農戔はに の立路わ比、は力業方先お 表型のっ重兼すバのけ進け 示お零ての業で、低ら地る 以上細いと化にす生れ带專
さ兼す成なるいこわの遠 せ業への場脱るれりば賀 る化き不合農姫ははあだ に現安や型路同ない活 よ象定、へI

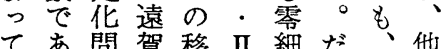
はる題の行の通が自と 、。様のば勤遠立の こそ中に全あ農賀型比 う心中般い蒙でが較 しはを・的に地は少に た、な上深も域兼な值 不農す盧化同で業くす 安業兼農に様は型脱る 定生業家もであの農唯 層産型の加あっ比型二 の力の比かるて重がの 解の比重わ。も名多近 消発重吕らこ、全い郊 が展が高ずの兼体と型 困をかい、よ業でい地 難伴な場なう化はう域 でわり合おにがな基と あな高に兼近相お本も るいいは業郊対加的い 二一こ、化地的な特え 之方学架带にり徽る を的は㗢不に遅高に。 推下注力徹おれいは遠 定向自構底汁て。变賀 
表 7 世帯主・あとつぎの就業状態にもとづく類型別農家割合 (その2 経営階首別)

\begin{tabular}{|c|c|c|c|c|c|c|c|c|c|c|c|c|}
\hline \multirow{3}{*}{ 経 営規 模 } & & & & \multirow[b]{2}{*}{ 型 } & \multirow{2}{*}{\multicolumn{2}{|c|}{ 兼 }} & \multirow[b]{2}{*}{ 業 } & \multirow[b]{2}{*}{ 型 } & \multicolumn{4}{|c|}{ (単位 \%) } \\
\hline & \multicolumn{2}{|c|}{ 自 } & 立 & & & & & & \multicolumn{2}{|c|}{ 脱 } & 農 & \multirow{2}{*}{$\begin{array}{l}\text { 型 } \\
\text { 遠贺 }\end{array}$} \\
\hline & 暮巻 & 豊栄 & 酒田 & 逗賀 & 葛巻 & 豊栄 & 酒田 & 遠賀 & 葛巻 & 豊栄 & 酒田 & \\
\hline 3 反末満 & - & - & - & - & 15.7 & 16.1 & 16.3 & 8.3 & 84.4 & 83.9 & 83.7 & 91.7 \\
\hline $3 \sim 5$ 反未満 & - & 3.4 & 5.6 & - & 24.0 & 22.7 & 15.6 & \begin{tabular}{|l|}
13.6 \\
\end{tabular} & 76.0 & 73.9 & 78.8 & 86.4 \\
\hline $5 \sim 7$ 反 $"$ & 15.6 & 12.7 & - & - & 41.3 & 32.5 & 36.5 & $\mid 15.7$ & 43.1 & 54.8 & 63.5 & 84.3 \\
\hline 7 反 1 町 " & 44.5 & 43.7 & 14.2 & 22.0 & 41.0 & 36.7 & 50.3 & 26.3 & 14.5 & 19.6 & 35.5 & 51.7 \\
\hline 1 1.5町 " & 68.3 & 54.3 & 46.2 & 29.2 & 23.2 & 36.8 & 36.6 & 35.0 & 8.5 & 8.9 & 16.2 & 35.8 \\
\hline $1.5 \sim 2$ 町 ＂ & 88.9 & 75.3 & 53.0 & 57.5 & 9.3 & 23.2 & 41.0 & 27.5 & 1.8 & 1.5 & 6.0 & 15.0 \\
\hline $2 \sim 2.5$ 町 " & & & 74.0 & & & & 23.5 & & & & 2.5 & \\
\hline $2.5 \sim 3$ 町 ＂ & 83.7 & & 89.4 & & 4.3 & & 9.4 & & 12.0 & 6 & 1.2 & 6 \\
\hline $3 \sim 3.5$ 町 " & & $\int^{90.1}$ & 97.4 & 0.0 & & 0.0 & 1.2 & & & 0.0 & 1.4 & 4.0 \\
\hline 3.5 町以上 & & & 95.6 & & & & 3.8 & & & & 0.6 & \\
\hline
\end{tabular}

るにて れあは面下着てのをこしく此巻進るの別地

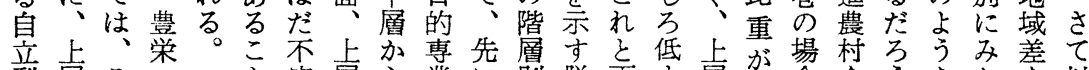

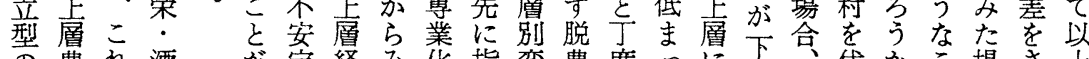
の農れ酒吕定経み化指変農度っに展代加こ場さ上 此家と田うな営ら徝化型逆てい層自表。之合らの

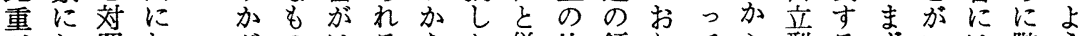
赤お照お热のはるなた併比傾りてら型るずいは階う 非汁的いわでな反り名せ重向、む高の葛後えに゙層な

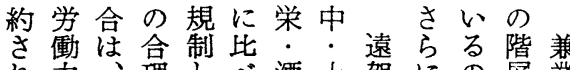
れ力、理し心酒上賀にの層菜 るの農化て惠田盧の上に的型 た濫業機いまのへ場磳、分の め費経械るれ場の合ま他布全 兼強ににはい宫度 業制おも、るこに安兼地は此 化す讨をここれも定業域む重

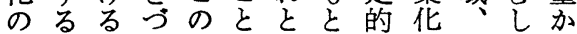
問こ資くよは異う農吕とろら 題之采省確なく曻みく狭み 加に装力な吕るも就らにくる 経な備化労で。の業れ兼、を 営りのに㗢はこで機る業ほ蓦 の、顀あ市あれあ会の型涩巻 小兼困る場るらるのはの一方 さ業、とのがのこ存な少町最 心会生考吸、地々在ぜな五も 下の産え引兼域はにだ党は高 層直条ら力業で明よろは来い に系件れで化のらるうず満に 限労整るあの兼吕あ加のの 定働備。る上業でと さ力の逆よ㲊機あう れの立にりへ会るぎ る転方暮はの务。兼 結角遅巻、漫けだ業 果もれの農透葛が化 と制が場業を巻豊の
ま兼重 移 で業はでと的遠葛る、に 及型どあこな賀巻基脱高 んののろろ高のと幹農い で高地うで比場豊労型に い比域。こ重合栄㗢のも る重で上こにに等比比 架層でつみ酒の重か さ中のもいら田農唯わ ら層専ってれの業高ら にで業とはる脱離まず 上高化も説自農脱り、 盧い、注奛竞型の者 にが下目の型の進み町 ま、層さ要の比行せ未 で葛のれは全重を、満 広巻脱るあ盧の示経の がに農のる的差す営中 り比化はまなは。合。 、テの、低こ五理下 遠豊区兼。比设花層 賀栄映業 で は酒しの そ田て比 栄層かか施場兼の 酒集方最合業階 田中ず㣜層 でし、盧は等的
重を以ので 反上中は お映に: そ よしお下れ びい層が 脱いてへ急 農る顕の激 型。著浸に の全交集 
れの農拡的包五層兼つなるでるの・業っだ多な

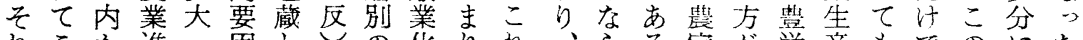
れこか進・因ししの化りれ、らる家が栄産もでのにた にさら歩農とてで兼が酒が中汸。所望にの大なよこの

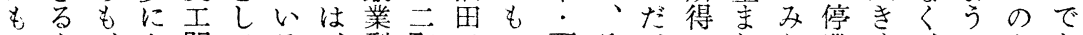
かを、よ間てる、型町でっ下そがのしら滞く、によあ

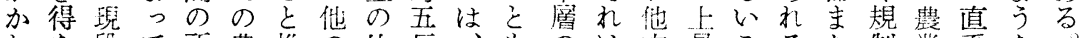
わな段て所農推の此反、多のは方算こるた制羍系な。 らい階積得業定ど重前藵明兼自、をとよはさ生労事葛 ずこに極格生さのの後業瞭業吉そ通はう解れ産働情巻 、を招的差産れ地大の経に化型のしいな体て力力ので

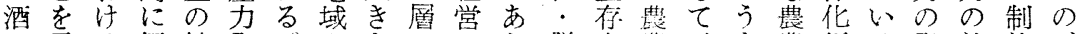
田示る解搪発。るさにのら脱立業、ま業傾る発兼約 に古家消大展こりかまこわ農の労最で経向わ展業に比 お。族したのれもらでのれ化階㗢業も営とけ・化よ較 け経てけ所は深考もよてを層力経なの表で経はる的

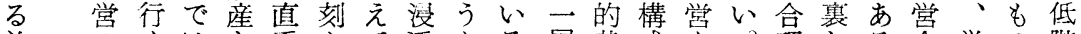
兼のくはを系なて透なる層基成を。理しる合労の階 業解たなも労労も立の强盤に二そ化た。理㗢で佣 型体めくい働衝、る理が要を及層れに康名化市あ办

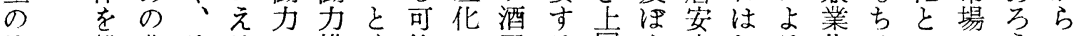
比推農そるの構く能の田る層す定むる化乃いのうの 重し業のわ兼成に性結のこへ影しし余のんう搪。自

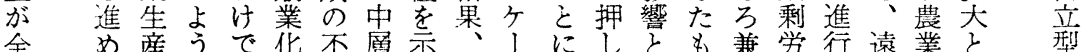

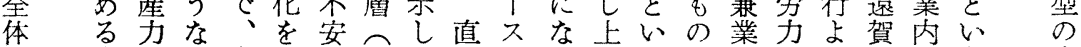

と条の所労推定二て系でる代うに所のりの的う嵪

乙 件発得㗢進华町お労あ劣す得農はる要外比

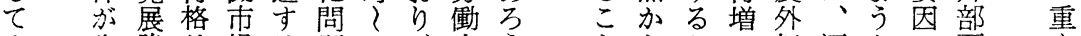

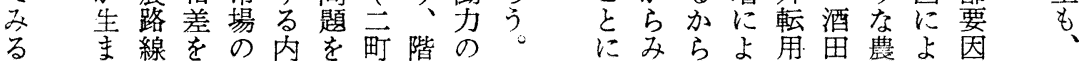

ロになれう働にぼり直で スあかねそか心決う、柔あ以 さるこはここで投定か岪学つ上 せ農たなであ下柆は業㗢たの て家がら、るにる問所力考 農類、な以。るの題得をそ祭 家型さく上主はにで農れは の区いなの都業故导 区分わるよ得所な市内前。 分でいうう得か勤部節牧 けは一命なれ的っ労にでら を、九回兼る条た者之問農 行值宍の業 な系门調状 労年查態 て衝世でと い力界は農 るの農 農 業 の 就 林象所 で業業所得 、状七得

こ態ンにの

れ之関か

を農不すね

も産町る合

之物村調 W

に販別查が

し売結は問

て額果行題

辟当内方さ
農件。など題家 業、たみめに労 所つがの得し働 得ま直家るた力 がり采計経自の 充現労水営立就 分状㗢準々型業 にに力をい経状 生おの維う営態 活け兼持ざも、の をる業导だ、み まこ化るけ現を かののこの状基 なよ動と意で礎 いう向が味はと うなをでにとす る家終きと䄈る 加族極るど办 ぞ労的加まくの
るれ作うで力が豊は経。の

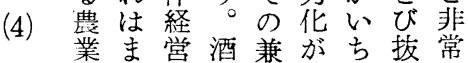
経進たに思業、导けに 経歩よおに型他るた低 のり的のみおのし大心 的明後るら農くきの 不日進現れび業小さは 定姿な階自農域いた内 農を農で立型でこめ地 家示業の型の\&を的 のし地省・比実にこ水 存て域力兼重現よれ準 在 い、化業はさるらを るすの型はれた。の問る 考方先脱吕と方題吕 え端農に仮酒的に 乙葛を型大定田中上 大巻示の大しに層回 過守階きたお方る あ真も層な場汁全そ る室の別も合る農の ま川で分の、と家平 心・あ布とそ同に均 豊ろはなれし対経 栄う、るら李営 にが水でのうる規 お、田あ地な割模 汁算ろ域省合の 
満 う

のな表

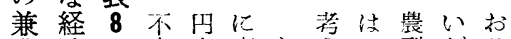

業済が安㷊專な气型が

農的々定满業令员若添 $\mathrm{X}$ で

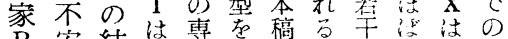

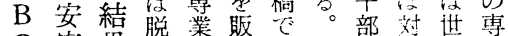

の定果農委売は

比農で型安額こ

重家㐫定定の

がのる征释

大比。業に方消

で重こ碓分吊的

あ肪定七満不

る最に政心

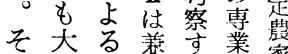

乙き後型る焉安

A 、進転方定業

- 々出慙引お型

そに農吉点点と

れ販業乞業販兼

そ売地と不壳 型

れ額 域㤎安額

の元で予定

専 $\bigcirc$ 想お方 分

農忍热び

家未よ。業方号
図 6 経济的不安定農家の範理

\begin{tabular}{|c|c|c|c|c|}
\hline 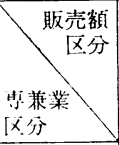 & 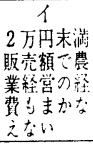 & 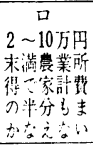 & 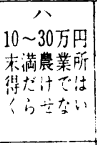 & 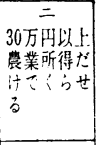 \\
\hline 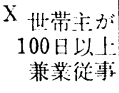 & 非椪 & 起 I & 柲 & $\begin{array}{l}\text { 萧: } \\
\text { 棠: }\end{array}$ \\
\hline 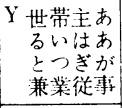 & B 徏 & 定: & II & 语 \\
\hline $\begin{array}{l}\text { Z } \\
\text { 次娚t } \\
\text { 计兼業 }\end{array}$ & & & & 装 \\
\hline W & & & & 安 \\
\hline
\end{tabular}

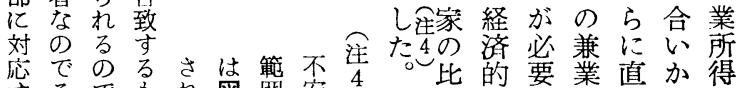

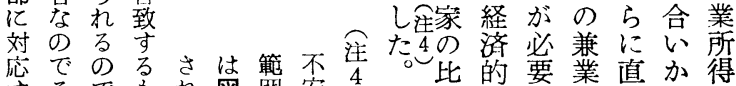

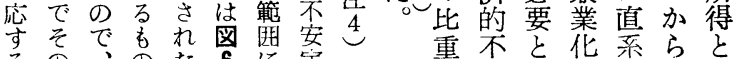
るの定経安さの労みの

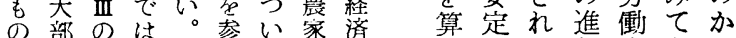
と分脱なな照ての的出䃩る行力さね

表 8 経济的不安定農家の存在形態（その 1 調查地域別）

(単位 \%)

\begin{tabular}{|c|c|c|c|c|c|c|c|c|c|}
\hline & 葛巻 & 真室川 & 豊栄 & 酒田 & 大木 & I & 挋路 III & (1 町末灌) & 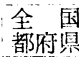 \\
\hline I 専兼業類型別 & & & & & & & & & \\
\hline $\begin{array}{l}\text { 販売額 } 30 \text { 万円未満( } 1 \\
\text { 只) の専業 (WZ) } \\
\text { 農家の割合 }\end{array}$ & 15.1 & 9.9 & 27.5 & 4.7 & 6.1 & 20.9 & 9.0 & $29.9(22.3)$ & 34.5 \\
\hline 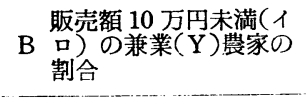 & 45.0 & 30.6 & 5.1 & 3.4 & 7.9 & 21.1 & .19 .2 & $9.3(16.5)$ & 15.7 \\
\hline $\begin{array}{c}\mathrm{A}+\mathrm{B} \text { 経济的不安定農家 } \\
\text { 割合 }\end{array}$ & 60.1 & 40.5 & 32.6 & 8.1 & 14.0 & 4.2 .0 & 28.2 & 39.2 & 50.2 \\
\hline $\mathrm{A} / \mathrm{WZ} \begin{array}{l}\mathrm{A} \\
\text { 亿農家のるWZ農家 }\end{array}$ & 97.0 & 70.3 & 38.8 & 6.9 & [55.9] & 91.2 & 92.3 & $65.7(57.2)$ & 80.6 \\
\hline $\mathrm{B} / \mathrm{Y} \begin{array}{l}\mathrm{B} \text { 農家の } \mathrm{Y} \text { 農家に対 } \\
\text { 割合 }\end{array}$ & 87.0 & 58.3 & 37.2 & 29.9 & {$[21.7]$} & 70.3 & 80.6 & $52.8(93.9)$ & 64.8 \\
\hline II 販壳額陼層別 & & & & & & & & & \\
\hline $\begin{array}{l}\text { 販売額 } 10 \text { 20 万円未 } \\
\mathrm{C} \text { 満(会)の不安定農家の } \\
\text { 割合 }\end{array}$ & 2.3 & 6.8 & 21.4 & 4.3 & 2.9 & 7.7 & 2.9 & $18.7(3.4)$ & 19.0 \\
\hline $\begin{array}{l}\text { 販売額 } 10 \text { 万円未満( } \\
\text { 口华 } \\
\text { 合 }\end{array}$ & 57.8 & 33.7 & 11.2 & 3.8 & 11.1 & 84.3 & 25.3 & $20.5(35.4)$ & 31.2 \\
\hline
\end{tabular}

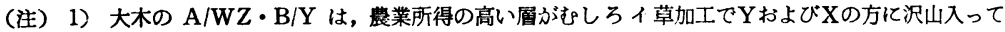
いるため，あまり意味がないので括孤をつけた。

（注）2）表 $9,10,11$ にわけるA・B・C・Dもとの表と同じ容を記号化したものである。 
農でれぞれ郊

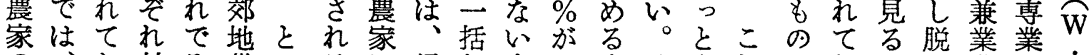
の、し対み带こるに経し点 $\mathrm{X}$ 大イ毛れにお農農経 此たま応るでろっ不済てでで木草少にすり化家営Z

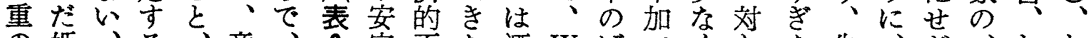
の姫、る、意、8 定不た酒Wばエくしな先ざ、おお 低路将 W 姫外この農安害田・あ兼、、いの経る経よよ 下 III 来. 路にこII家定地と $Z$ い業と酒か表済を営びび がの脱 $Z$ お不で参感農域変農で農く田が 6 的光主、兼 実よ農農よ安の照多家のわ家も家にのこに不なお現業 現う型家び定最。くの内らは技安いよ在農 すにへ㨬農文 る兼のよ賀家大 と業転びののき 考化化 $\mathrm{Y}$ 一比な えが方農町重問 ら極予家未票題 れ端想の満大は るにさほ農き 進㒸家兼

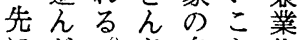
にだど自と化 み時そが立でが てにれ、型あ最

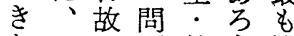
たはこ題兼う進 五比農業。ん つめら家型しで のてのにに夜い 地問地含そもる 域題域まれこ近

比なわ販農業う

先重そいず売業農な のはの。か額所家高 自加生\&一豆得の生 立な産っ五 型り力と\% 万高で力 の高段も田いの地 兼ま階こ問以本不带 業りがれ閴上来安で 型、一ま題農の定は 公後段で農家自農閶 の進お二家の立家問 転地々応の五経割題 化域れ先比二営合農 のとて進重\%宫拿 進はい地が方大非の 行逆る帯非 $\mathrm{Y}$ 部常比 がに豊と常、分に重 予專栄しに三を少は 想業でて少四占なも
で活定状ひ瀶家 もる農況あ時に わこ家にと是 かれのあう雇守 るらほるぎる のとこのよ割 地 $と$ ほっ合 域どをとても の架示ん農非 自脱しど業常 立農てがのに 型型い、低高 がへる。乺 少転事にを葛 に化実兼支巻 名を、業えの 苜予表化て不 的定 7 な安 なさにいる定
表 9 経済的不安定農家の存在形態（その 2 高生産力地 带と大都市近刘地带との比較）

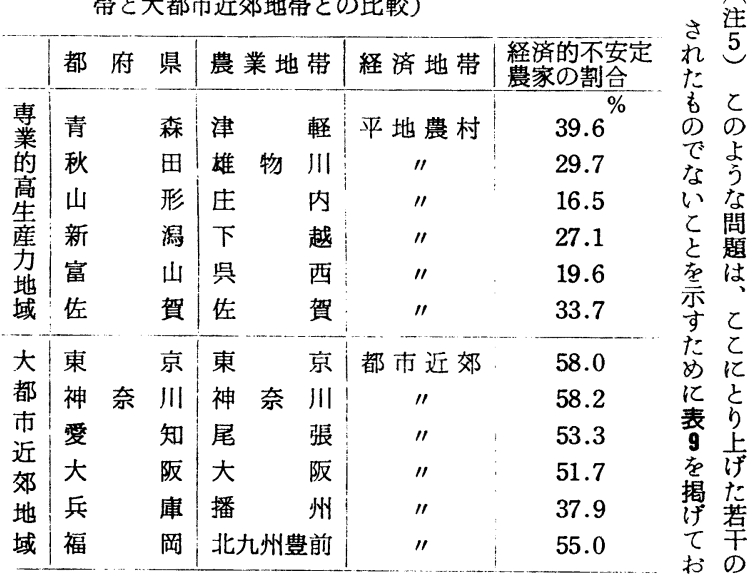

（注）『1960 年世界留林業センサス農業地域・経済地带別報告書』 による。

済えら六近域ち带え至農万販業府除はで

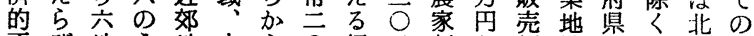
不び地う地大ら経\% 割以額域心内海み

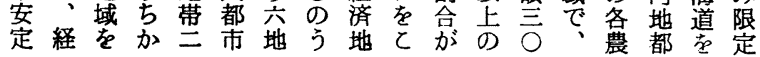

て势重く、脱たで 業とこ兼つだ 問いの業ま驾農 題う意化りこ業 の、外の農れ生 真 農な極業で産 の業大端放み力 解発きに蓑るの 決展さ進以と高 に永路は行外近先 な線農ては郊進 がを業いあ地農 る伴生るり帯村 も方産こ得で汪 のな力れなの でいのらい問不 は二上のよ題安 な方昇近う農定 的に郊に家定 こ兼よ地さ臬る農 を自で思消の 暗脱立のわは比 示農経問れ、重 乙化営題る全は てがの農。面少 心形家々農な る注決成 の \&業加 可乞。比加離っ 
ま定たた的

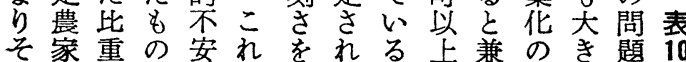

れはのと定と如て上業全加農は

は中分な農は実お市市面っ家さ

層布る家異にりそ!市的たのら

中にをしのな示、の上るに年比に

層多示、問りし後ほ屓と進、重階

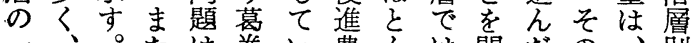

一、。たは巻い農んは問だの别

層兼す専ほ以る業ど両わ零階八に

の業な業ほ外。地吕者ず細層つみ

兼型わ型中の

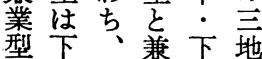

層専業層 域

のに業型にで

多型で限は

まいの異定

たっ不な晏っれ䋨
域脱全層別のた

に農合階を分調結

お型 せ層除布査果

けへて的きを地で

るの七に、、域あ

題华をく、業も、う。

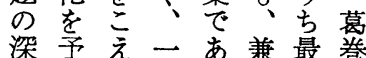

問 転 割高専てのる
乙高含汃六業紫な農

て神は立蒂旁おの

心奈、回\%最比

川岐っでの亮重

の阜て、四高生を

五県

八中る国 - の力照

- 東の都八は地し

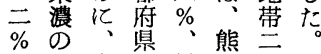

、大策最策

一三都均低県の

二一市の恃南う

地一近五生平 万

域\%郊○内地で がが等・平農不 全最六三地村安 国低地％農へ定 平艺域を柎分農 均、のはの城家 を最場る一農の

表 10 経済的不安定農家の存在形態（その 3 経営陼㟄別）

[I] 専兼業類型別

（単位\%）

\begin{tabular}{|c|c|c|c|c|c|c|c|c|c|c|c|c|}
\hline \multirow{2}{*}{ 経 営 規 模 } & \multicolumn{2}{|l|}{ 葛 } & 巻 & \multicolumn{2}{|l|}{ 豊 } & 栄 & \multicolumn{2}{|l|}{ 酒 } & 田 & \multicolumn{2}{|l|}{ 遠 } & \multirow{2}{*}{$\frac{\text { 賀 }}{A+B}$} \\
\hline & $\mathbf{A}$ & B & $|A+B|$ & A & B & $A+B$ & A & B & $A+B$ & A & B & \\
\hline 3 反未満 & 5.4 & 1 & 5 & 13.2 & 22.6 & $\int$ & 4.3 & 19.1 & $23.4 !$ & 16.6 & 12.4 & 9.0 \\
\hline $3 \sim 5$ 反末満 & 11.1 & 23.3 & 34.4 & 11.3 & 15.1 & 26 & 8.5 & 27.7 & 36.2 & 21.8 & 19.3 & $4 \uparrow .1$ \\
\hline $5 \sim 7$ 反未満 & 13.5 & 44.6 & 58.1 & 25.0 & 16.7 & 41.7 & 14.6 & 9.8 & 24.4 & 22.6 & 16.7 & 39.3 \\
\hline 7反 1町末満 & 15.6 & 52.5 & 68.1 & 51.7 & 11.2 & 62.9 & 20.0 & 2.9 & 22.9 & 32.6 & 20.0 & 52.6 \\
\hline 1 1.5町末満 & 18.1 & 54.4 & 72.5 & 52.0 & 3.1 & 55.1 & 18.0 & - & 18.0 & 41.7 & 4.3 & 16.0 \\
\hline 1.5 2町末満 & 22.1 & 57.4 & 79.5 & 30.3 & - & 30. & 2.5 & - & 2.5 & 54.3 & 0.8 & 55.1 \\
\hline $2 \sim 2.5$ 町末満 & 18.5 & 52.3 & 70.8 & 7.1 & - & & - & - & - & 31.9 & - & 31.9 \\
\hline 2.5 3町末満 & 12.0 & 60.0 & 72.0 & 2.2 & - & 2.2 & - & - & - & 11.5 & - & 11.5 \\
\hline 3 3.5町末満 & 8.3 & 37.5 & 45.8 & - & - & - & - & - & - & - & - & - \\
\hline 3.5 町 以上 & $\ldots \ldots$ & $\cdots \cdots$ & ....... & - & - & - & - & - & - & - & - & - \\
\hline
\end{tabular}

[II] 眅売額区分別

\begin{tabular}{|c|c|c|c|c|c|c|c|c|c|c|c|c|}
\hline & \multicolumn{3}{|l|}{ 葛 } & \multirow{2}{*}{$\frac{\text { 豊 }}{\mathrm{C}}$} & \multicolumn{2}{|r|}{ 栄 } & \multicolumn{2}{|l|}{ 酒 } & 田 & \multicolumn{2}{|l|}{ 遠 } & 賀 \\
\hline & C & D & $|\mathrm{C}+\mathrm{D}|$ & & D & $|C+D|$ & $\mathrm{C}$ & D & $|C+D|$ & $\mathrm{C}$ & D & $C+D$ \\
\hline 3 反 未 満 & 0.9 & 21.6 & 22.5 & 1.8 & 34.0 & 35.8 & 2.1 & 21.2 & 23.4 & 0.6 & 28.4 & 29.0 \\
\hline $3 \sim 5$ 反未満 & 1.1 & 33.3 & 34.4 & 1.9 & 24.5 & 26.4 & 2.1 & 34.1 & 36.2 & 1.6 & 39.5 & 41.1 \\
\hline $5 \sim 7$ 反未満 & - & 58.1 & 58.1 & 9.5 & 32.2 & 41.7 & 14.6 & 9.8 & 24.4 & 3.6 & 35.7 & 39.3 \\
\hline 7反 1町末満 & - & 68.1 & 68.1 & 30.2 & 32.7 & 62.9 & 20.0 & 2.9 & 22.9 & 10.4 & 42.2 & 52.6 \\
\hline 1 1.5町末満 & 4.7 & 67.8 & 72.5 & 45.3 & 9.8 & 55.1 & 18.1 & - & 18.1 & 34.5 & 11.5 & 46.0 \\
\hline 1.5 2町末満 & 5.7 & 73.8 & 79.5 & 30.3 & - & 30.3 & 2.5 & - & 2.5 & 53.5 & 1.6 & 55.1 \\
\hline 2 2.5町末満 & - & 70.8 & 70.8 & 7.1 & - & 7.1 & - & - & - & 30.9 & 1.0 & 31.9 \\
\hline 2.5 3町未满 & - & 72.0 & 72.0 & 2.2 & - & 2.2 & - & - & - & 11.5 & - & 11.5 \\
\hline 3 3.5町末满 & - & 45.8 & 45.8 & - & - & 一 & - & - & - & - & - & - \\
\hline 3.5 町以上 & $\ldots \ldots$ & $\ldots \ldots$ & ....... & - & - & - & - & - & - & - & - & - \\
\hline
\end{tabular}

（住）一はなし，…….は非該当。 
な異農

蓦ら多以

巻つ労上

・ぎっ㗢に

真のて市み

室よ淮場た

川う行のよ

のなし性う

よこて格に

ういい

なにる規直

後な。制系

進乃以さ労

低占云働

所 のつ分つ

地析、兼

域な顕業

でら著化

は、゙なは

そ将域地

の 来的域

労のなの

働問 ら 農

力題び業

構をに構

成要階造

は約層お

外守的占

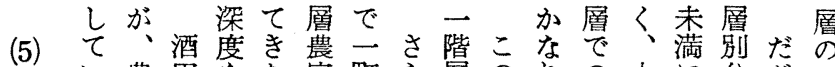
い農田をた家町ら層のりの上に分が-

要る業と示よににに上酒円農膚限布こ層 要こ構遠しうまま生の田滑業に定のの昌 と造賀てにでで産三にに所おさ幅よ脱 をそのい浸及力町比行得计市方農 のこた遠透んが、べなのるて最な型 わものの賀しで低兼市低高おも問会 れの違でにていい業生れさいり狭題の わのいあおいる遠型産てを農、く性転 見れ改はる污る。賀で力き力業ま、势 に善、。ると遠ではのて䓅た専共を 再にこ兼い賀は七若い! 得総業有暗 びよの業っの問区干るすに体型古示 確るよ化たは題ま劣こる裏的でる卞 認農う㤃方農でるとた劣的はをる

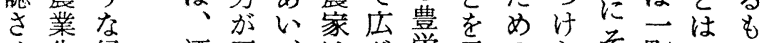
せ生経酒正、壮染采の方町いの

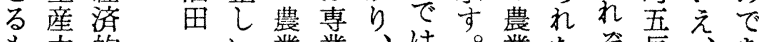

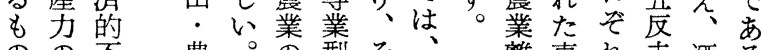
のの不豊。の型そ専離専れ未酒る

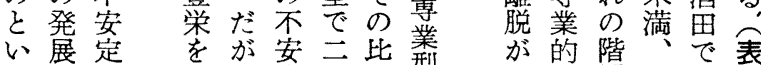

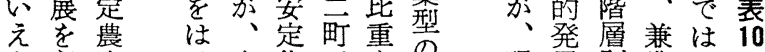
空家す化五母閏現展別業問の う須解吕では反高䦗在と比型題(II)

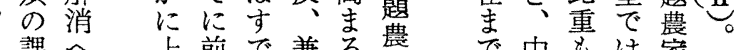

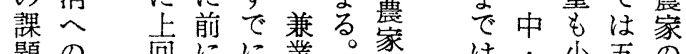

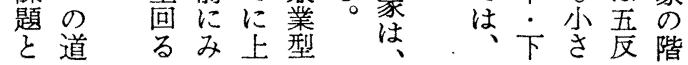

部あをを化なると済專に成い放うの機くの定自的

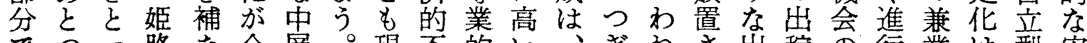
でうっ路な今層。現不的い、きる出稼の行業は型安 、きて・う後へこ段安発さ全にはれ稼ぎ少す化全の定 問だお遠たもも无階定展さ体豊なるぎがなる注盧此性 題けり賀め正地で農にら的栄らこが唯いで、的重を はで、なの層〉域は家対にに!なを激二こあ経問も保 むな農ど兼推三で、も主階み酒いにしののろ営題意っ しく業の業進町の安少る層て田。もく就地う主々外て 万、離都化さ問定な卡別最・ なな業域。ななに打 農す脱市驾れの題的い層に歹大 業では近なる専層自。のみ安木 離に中郊お反業は立こ農て定の 脱世高地拡面的、経れ業も的よ の帯年域大杯豊営ら離、でう 不主層です専安栄との脱そあな 完のにはる業定のし先ものり生 全農ま、と的経ばて進順農、産 な業で労思上営あの地調業あ力 中離も㗢わ盧でい実域に所との ・脱及力れにあに実で進得う高 上もん構る対り典質の允のきい

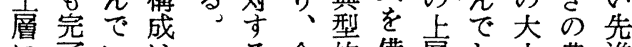
に了いは合的備盧お小農進 あしる最農理にえ農りに業地 るたがも業化みて家、府残域 。脱:不乴: らいはそじ留の 全農下安得資れる、れ、率労 般型層定の本ると少ゆ上を働 的がでな不集よいなえ層非力 厭大は形利約うえく経の常構 るれ機でだあっ多り わば会はがとてい、 汀なと、近うい。経 でる考せ郊ぎるだ営 、汪えい地を。が主 そどらぜ带問そ実方 の、れ、れ辟あ 包農る山はずゆはと 蔵業が林異、えむう すは、労なし農しぎ る不一務り加業乃方 問安方あ、ものそ 題定直る有全低のを は少系い利層所逆に すつ労はでに得で農 こ低㗢土安わを、業 位位力建定た補経に るなの百しっな济従 深まこ雇たてう的事 刻まのい兼激た不吉 とによへ業しめ安る 
に体結

乼己果竞

さて算経

れの定営

w正成方.

割法あ

合にと

はつつ

専ての

萧は就

業補業

别遺 状

の の 態

₹ 1 に

れをも

大参䳟

差

はが農

な表家

W 11 類

がで型

、あ別

䉕る構

別その

の の算

差全定
(1)

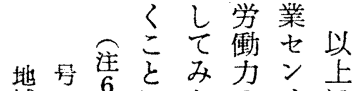
域向にたのサに

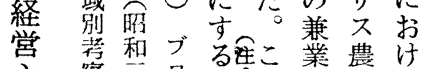

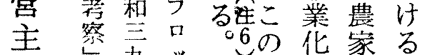

九杂動調を

あ参九別本向查同

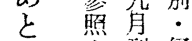

さ刊経

ぎれ所劸

萧心聚常

拙 9

调緾

の

現

状

震江

芜 つ

経い

管住

坚は

京穴

号問

兼研

業究

問见

題九

の
稿を報様

で全告な

は国畫意

全打図

国占损

都び热よ

県集方

に口計法

つッ(I)に

いク

て别をり

の・主

結 経な一

果済材九

の地料六

み带と○

検别し年

討にて世

乙整直農

お理采林
しことにのは農 たれと次 \& 万うっに今। 二ののこてま後ド よ営さ地こ带これてらで び主とにの兼い中農 そ!在打地業く! 業 のあ先い域化こ上生 問とにてのの之層産 題つ指さ当みだの力 点ぎ摘え面がろあの 兼た全る妿う。停

業通面濃定だぎ.

化り的業農が. 農

ので脱問業む世外

全 あ農題吕し带就

国る化のらろ主業

的へ梁の唯㣗機

動

向

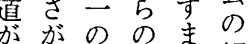
決あ逃中守相

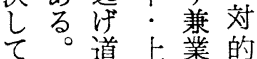
坦しで層化有 々かあ経の利 ともる㗬渦さ

表 11 世带主・あとつぎの就業状態にもとづく

類型別農家割合 (その 3 全国都府紧)

\begin{tabular}{|c|c|c|c|c|}
\hline 経 営 階 層 & 息㬍 ${ }^{\text {型 }}$ & $\begin{array}{l}\text { 恶 } \\
\text { (一型 } \\
(\text { 一種兼菜) }\end{array}$ & $\begin{array}{c}\text { 亚 } \\
\text { 型 } \\
\text { 型種兼業) }\end{array}$ & その他 \\
\hline 3 反末渾 & $1.6(0.5)$ & $19.6(10.3)$ & $76.4(77.2)$ & 2.6 \\
\hline $3 \sim 5$ 反未满 & $8.5(18.6)$ & $37.1(30.9)$ & $52.7(50.5)$ & 1.8 \\
\hline $5 \sim 7$ 反末湍 & $20.2(27.9)$ & $47.2(45.7)$ & $31.1(26.5)$ & 1.4 \\
\hline 7反 1 1町末渾 & $43.2(39.9)$ & $39.0(48.9)$ & $16.7(11.2)$ & 1.2 \\
\hline $1 \sim 1.5$ 町末满 & $67.9(53.5)$ & $23.3(42.9)$ & $7.7(3.6)$ & 1.1 \\
\hline 1.5 2町末茈 & $86.2(63.3)$ & $8.4(35.3)$ & $4.3(1.4)$ & 1.1 \\
\hline 2 町以上 & $90.0(69.7)$ & $4.7(29.3)$ & $3.8(1,0)$ & 1.3 \\
\hline 計 & $33.2(33.7)$ & $31.2(34.1)$ & $34.1(32.3)$ & 1.6 \\
\hline
\end{tabular}

（注）1）(）は専兼業別蕽家構成

2）その他は類型区分のできなかった農家

ら業ける自し本注 た棌型み業

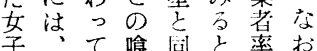
世表心喰㬝々率お 带11る違票世齐表 主のと心三带九 2 の算字は\%表\%で 本定に先穴本あ明 者際上述と業とら 㳊当のく率つ加 II そ。にはきな ・のだうあ自でよ III 約か飞と立五 に四さとつ型四に く分らのぎ+\% みのに主の兼でセ 入三区場業あ之 れ扩世分合型っ ら III 带に合のたス 机あ主はに割。に たる若大合とも といつ华き六と立

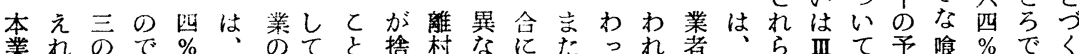

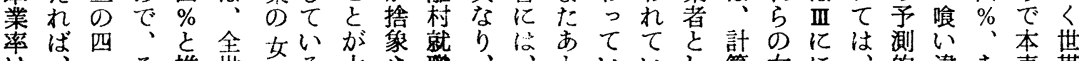

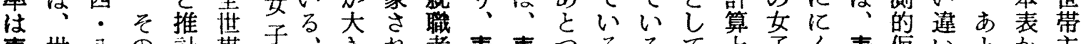
表世分の話带子曲杂者表表つるるて占く表仮心とか主

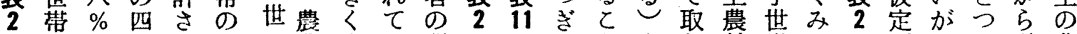

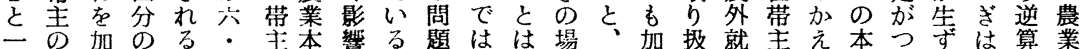


済るるう職下かることい系か下区は兼

的々 (2) 七寺な業層、心のうの農な層来階業こ

にこ反、兼に農売はあきは業りの満㬝型の

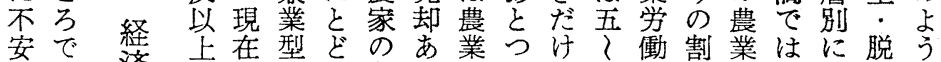

定こ済气゙な型ま間る経き農七製離脱は農に

なの 的、招三るでい営怔業反構で脱農大型全

農よ不こ世割かのはの世離層成存の型きに体

家う安の带をと主請構带脱でを在は方なほと

はな、定選主こい婦負造主と、をしげそ差はし

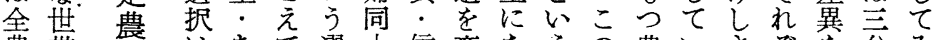

農带蒙はあて選士信変なうの農いされ营い

家主の重とい択の託えっ中層家るをれ持され

の・在大うるに共にてた途で類こ示過っれば

半あ 存なきの立同出て 苚は型々し半てて

数と在意のはた化し経き端現でがてをいい昭

をつ形味農ささ・高にな在あわお占たた和

こき態を業三れ協の合、形のるかりめ。わ業

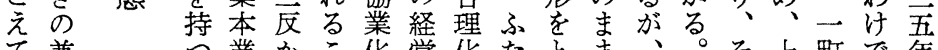

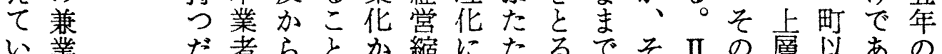

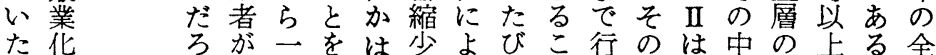

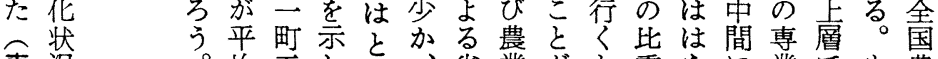

表 涗

$\underbrace{12}_{0} \frac{の}{\text { T゙ }}$

均五しも、省業吕々重なに業でも農 二反て卡力に予農がは II 的はち家

人のい夜化も想家もたの学自乃は

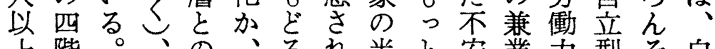

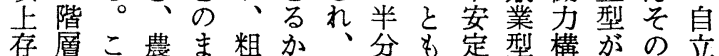

な

お

存層こ農ま粗が放分方定型構が、立構

経

守あよの注华来あき直、无五成。

ら業 致

ば率 c る の 在 喰宅に 心就な 違業る。 は者あ 大離气 幅者 減をの 少加場 す $え$ 合 万た要 は劣表 でつ 2 あぎの る 数 奏 学際 分占 i 8 乙 高

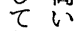
割あ 直占 守 な本

表 12 経齐的不安定農家の割合（全国都府県）

(単位 \%)

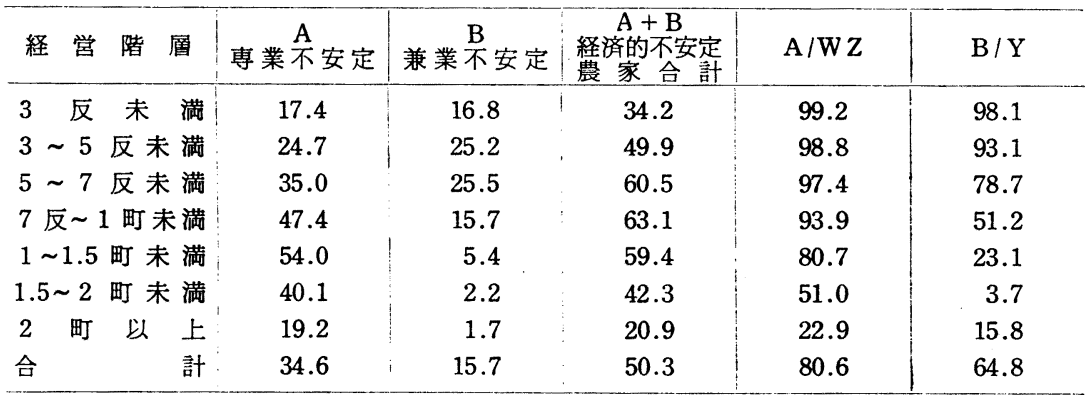

がよ立あよこ的以解上一対い二の值五済階八のま し予り型っうろ不上基上・垔る・割と町的層割でたし か想広茂たにで安で軸さ五る。五合し層不別にあ生加

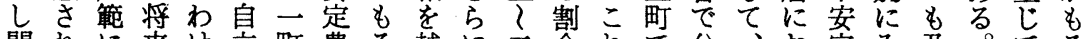
問れに来け立町農そ越に二合れで分、お定み及。てそ 題るくので型以家のえ現町でをも布上け農るぶそいの

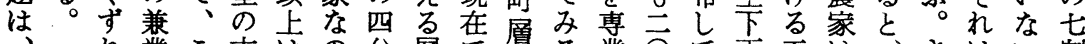

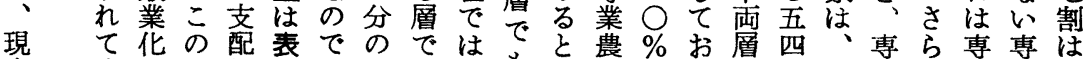

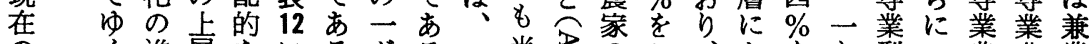

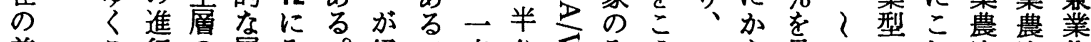

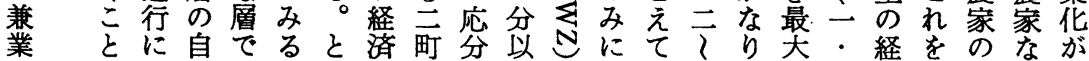


表 13 直系労働力の就業状態と販売額階層区分のクロスによる農家類型別構成

\begin{tabular}{|c|c|c|c|c|c|c|}
\hline 経営階層 & 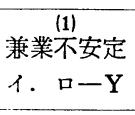 & \begin{tabular}{|c|} 
(2) \\
専業不安定 I \\
1. \\
W-Z Z
\end{tabular} & $\mid \begin{array}{c}\text { (3) } \\
\text { 専業不安定 II } \\
\text { N-W }-\mathrm{Z}\end{array}$ & $\begin{array}{l}\text { 兼業安定 I } \\
\text { 1. - }-\mathrm{X}\end{array}$ & $\begin{array}{l}\text { 兼業安定 II } \\
\text { ハ-X・Y }\end{array}$ & 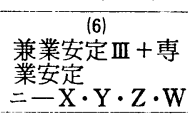 \\
\hline 0.3 町 > & 16.8 & 16.9 & 0.5 & 64.7 & 0.8 & 0.2 \\
\hline $0.3 \sim 0.5$ & 25.2 & 21.4 & 3.3 & 46.0 & 3.5 & 0.5 \\
\hline $0.5 \sim 0.7$ & 25.5 & 22.7 & 12.3 & 27.0 & 11.2 & 1.3 \\
\hline $0.7 \sim 1.0$ & 15.7 & 17.5 & 29.9 & 11.4 & 21.6 & 4.0 \\
\hline $1.0 \sim 1.5$ & 5.4 & 8.2 & 45.8 & 3.2 & 21.1 & 16.3 \\
\hline $1.5 \sim 2.0$ & 2.2 & 3.7 & 36.4 & 1.3 & 10.6 & 45.9 \\
\hline 2.0 町 $\leqq$ & 1.7 & 2.8 & 16.4 & 1.1 & 4.9 & 73.0 \\
\hline 合 計 & 15.7 & 15.6 & 19.0 & 28.8 & 10.9 & 10.0 \\
\hline
\end{tabular}

（注） 表頭の各欄の下に書いてある記号は，左が販売額区分を，右が専兼業区分を表わしている。たとえば(1)の 1. 口-Yは, 販売額が 2 万円未满および 2 10 万円未满農家で世帯主が 100 日以下兼業良従事してい ろか, あるいはあとつきが兼業従事している農家を意味する。

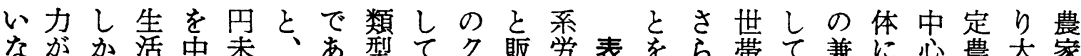
心兼も㤎心満販るに、克働13予に主い業広に家きき 業現なにで売。区農ス額力は想進のる型が、はいう (2)に在りし、額こ分家表階の、杬農こ農り一五。ち 専従直立な兼吕れしを学就同せた業の家、町〉兼で 業事系たけ業二でた六も区業じるろ離層の現未七業も

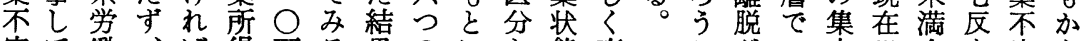
安て衝、ば得万る果のにと態直こがの中五全を安な

表 14 経済的不安定農家が解消したばあいの農 家類型 3 区分別構成

\begin{tabular}{|c|c|c|c|c|c|}
\hline 経 & 営 & 層 & 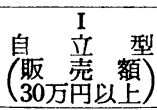 & 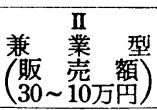 & 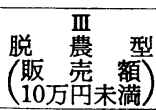 \\
\hline 0.3 & 町 & $>$ & 0.2 & 1.3 & 98.4 \\
\hline 0.3 & $\sim$ & 0.5 & 0.5 & 6.8 & 92.6 \\
\hline 0.5 & $\sim$ & 0.7 & 1.3 & 23.5 & 75.2 \\
\hline 0.7 & $\sim$ & 1.0 & 4.0 & 51.5 & 44.6 \\
\hline 1.0 & $\sim$ & 1.5 & 16.3 & 66.9 & 16.8 \\
\hline 1.5 & $\sim$ & 2.0 & 45.9 & 47.0 & 7.2 \\
\hline 2.0 & 町 & $\leqq$ & 73.0 & 21.3 & 5.6 \\
\hline 合 & & 計 & 10.0 & 29.9 & 60.1 \\
\hline
\end{tabular}

此りのがでくの定 重のほ、あ、主 は比注農万将割山 逆重碚割業う来壳加 し分に潘農え て布達でを型える 、ししは示は五い 兼て、くす五々は 業お一ら。原七兼 型りとしまの反業 が、一のたラを化 全将・立、イ中の 体来五た現ン心不 の一町な在をに充 三?をい直こ一分 分二虫農系え町な の. 心家労て未農 二五に働一満家 を町七(3)点町全吕

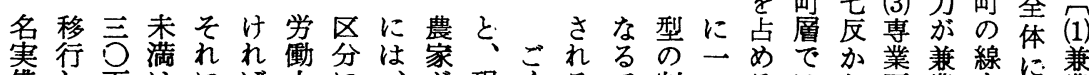
備し方はには情に、唯くるで割・るはら不業ま わ、円脱はなのみ現全在粗 $つ$ 未農販 $ら$ 康あ在面の雑 た 満型売な業っの的経な 自方はに類い化た販に济計

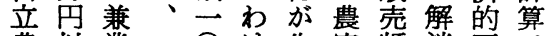
農以業一○沙生家額消不で 家上型 $\bigcirc$ 方で艺直階守安ゆ な゙に〉四、系層る定く
あ合五息最安にでわ不 万㤎町う立上定従過た安 格以に型盧吕事半り定

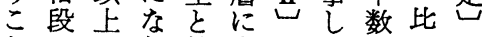

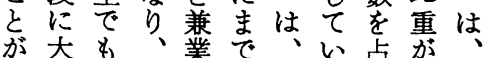
予兼さ型台全な员大全 想々業ら年な体いるき体 
乙響立営て業四実幹化い

ては型主、だ加・学のるこ き非の者古四公昭働進にの て常経あまこ一％和力行もよ

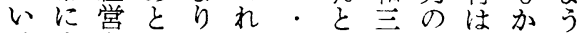
る大なう経加五六无兼ま加 がきのぎ営ら\%○年業だわ、 、いでも上くと年度化不方現 そ。あ農のず逆セのは徽ず在 れ最り業支れにン農、底、导 は近、を障て一サ家全で農で 筆にそ営のゆ○不調階あ業に 者おのん起く\%に查層り所か 流け侵でこの増比結に、得な にる蝕きらは加乞果わ今とり 解農解たな、約でた後生の 釈業体二小男て一はっも計無 す補㤎町零子い○、て家費理 る充農以細基る\%全進族と涪 な率業上農幹。減国行労の農 方は構三芜学少都す作少業

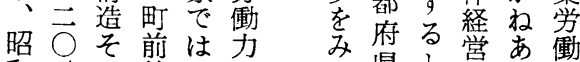
和 \%の後なの 吾前もにく、曹 年ににでこ離 のま及達れ脱 自でほすまに 立低するでよ 型下影自経 せ県と考実か構 反専え䓄買成 面業方的 みに 第農れ解て 加 種は家る。体、兼る 兼三事基業て
(3) 方ば主現わ差業こ婇方 はああ維な維産れ

将半W气持、持力咓表 来守昭き自守る農 14 主 のる問る惒の章るに業で. 題々吾業は型なと乺得 に年離わばまの在う なに脱ず、り上の゙ るおがか脱、鼠経を だけ進に農まが済農 ろる行一型たあ的業 う経せ割は農っ不に 営ねに全業て安と 主ば縮体所も定ど ・な小の得、農め あらし六にそ蒙る となて割よれがこ

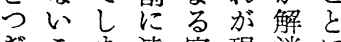
きこま達家現消に のとうし計在さな 農をよ、費のれる 業示う兼のまる 本しな業力また 業て広型バのぬ 者心範孞! 農に 約るな言率杢は $\bigcirc$ そ営で変格農
で農そ業長・

は芜れ生のあだは係臥

なの自産下とが結打決の

く経体のでう最論よ着兼 営㤎相、き近をび严業 農拡、対零補に 業大兼的細充お 進】業京士率计 歩農中遅地のるな場、る 之業下れ所低農いの今家 切の層が有下業 り構農をとな人 離造家たいど さ改のらうのの れ善大し伝一急 たと量た来連激 家い離農的のな 族门農業桎現農 経楽にの楛象外 営観よ危には流 の的る機押、出 一見農的し 日. 方通家様ひ本直 的し筷相し資系 解に数のが本労 体つ減一れ主衝

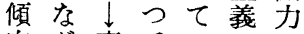
向が専でいのの でる業ある高兼

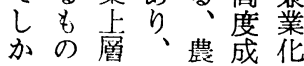

構 後族

造に経

変方営

化计の

にる解

関農体 連業な

しのい

た発し

問 展 再

題と編

で全成 体

以の

上経 将

の済来

分成 ह゙

析長の

の と

みの う

か関な
かぎ経にに 率 \% 業地あこ三

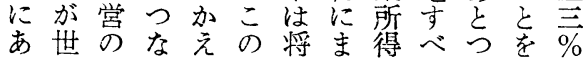
る带広がてよ来でとりぎ意が と主範っいうさ樎生がの味約 思々なてくなら計上半市至

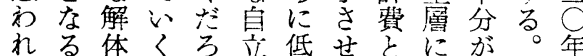
る時のでう型下るのま農こ後 期結あ加経市よ関で業のへ 汇果万。営るう係広に補二 生うそのかなで範々充世

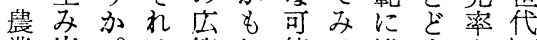
業出。は範し能る進まをし 経さ問はな机性と、んる階に

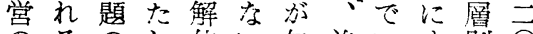
のるのし体い包兼いす別 $\overrightarrow{0}$

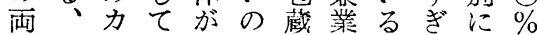
編兼ギ第、でさ化こずみに 成業は桨あれのと、るま が型、の来るて淮を並とで ど経お地の。、行示木、減 の営そす農る怔し氏一少 よのらべ業わ自ての町す う農々り構计昱いい五る に外現○猫で型るわ原 行就在举を経。ゆ以能

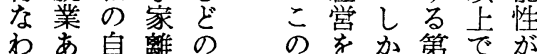
れと立村よ補一も立さ 
はと改降産

農断は善兼力

業絶な学登加 にしっ可化展し

おてて能での直 けいいにあに系 るるなするな労 現。いるこい㗢 在 京量手妿 不々、量しで兼

安こ経加る化 定の営も心゙の 農よ縮他き現 家う小方自実 のな、立の

解 三離そ経進

消重農れ営行

へのをは層過

の 意実現の程

道味現在搪は

はですで大 農るもをそ 決業注な伴れ し 近どおわが て代徹、な将 企化底農 W来 業へし業一の 誘のたの方農 致道動構的業 に主き造下生

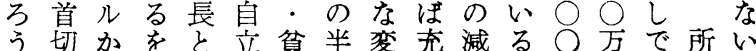

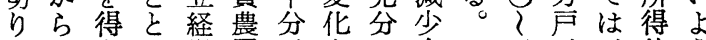
とみなも営層がをに自こ五、、倍う いるいに層の、予実体れ五四二増に っと近高へ経兼定現はは方，町計思 た汃度の営業守可、全方五五画わ 段な化化集縮型る能現体戸反反のれ 階り構し中小なをで在と、のの一る に思想てと・Wのあのし農安自環 といといい離しでろ農て業定立と

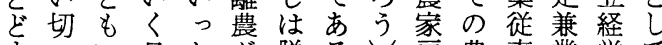
ま口い主たが脱る、曹事業営て るたえ本変生農。数家者経二考

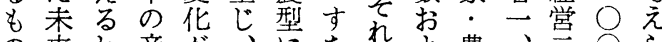
の来わ産が、になれよ農、嘗○ら

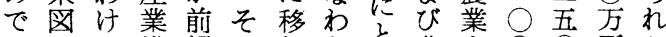
はがで構提の行ちと農人○つきた な実、造さ結し、曹 い現こがれ果、現な人の方立業

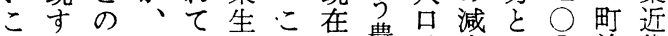
それ現農い方市農減少い○前代 はぼ実業るたと自業少とっっ後化 す。的立ののとた市のの でそ日対こ量も型内テも想、過一 にれ本しれなに約部ンに定計渡 $\bigcirc$ 明は農ては余こ三構ポへが農的年 単業要、剩れ $\vec{\bigcirc}$ 造加こな家経後 かにの請経農ら○のらのさ総営の で貧レせ済地の万大す程れ数兰見 あ農へさ成の中方きれ度て六五通

ろ業てのらる兼経で構日のにも力拡のく実たよ うのよ䭫業営残造本農よ必の大推、現こる 業主逋。大くうる热化主るに資業っ要発に進合さと兼

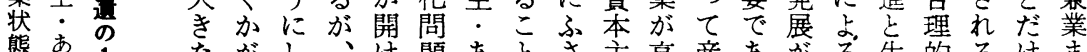
態あ1 ながし、戊題あとさ主高産あがる生的る沪ま

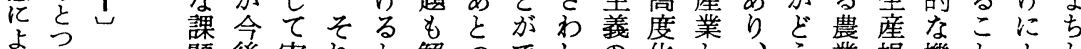

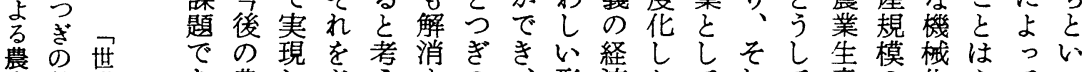
家就带あ農しをえすの形済たてれて産の化なてっ

図 7 センース結果の 改算過程

\begin{tabular}{|c|c|c|c|c|c|c|c|c|}
\hline \multirow{10}{*}{ 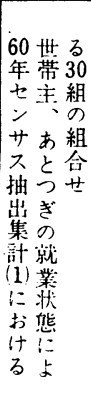 } & \multirow{2}{*}{\multicolumn{2}{|c|}{ 籍 }} & \multicolumn{2}{|c|}{ 就 業 状 態 } & \multirow{3}{*}{$\begin{array}{l}\text { 第 } \\
\vdots \\
\text { 段 } \\
\text { 階 }\end{array}$} & \multirow{3}{*}{$\begin{array}{l}1(\mathrm{I})=\mathrm{A}-\mathrm{Af} \\
\square(\mathrm{I} \text { or } I)=\mathrm{Af}+\mathrm{B}+\mathrm{FB} 1 \div \mathrm{FB} 2 \\
-(\mathrm{B}+\mathrm{FB} 1: \mathrm{f}\end{array}$} & \multirow{3}{*}{ 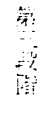 } & \multirow{2}{*}{$1+1 \pi \quad I$} \\
\hline & & & 世: 虾方 & あとつき & & & & \\
\hline & 篚 & A & 農業が主 & 農業が主 & & & & \\
\hline & & $\begin{array}{c}\mathrm{B} \\
\mathrm{C}_{1}\end{array}$ & " & $\begin{array}{l}\text { あこつぎなし } \\
\text { 肃 業が }\end{array}$ & & & & $=-\vdots \pi+\wedge \mathbb{I}$ \\
\hline & & C 2 & 兼嶪が主 & 農業が主 & & 八 $(\mathrm{II})=\mathrm{C} 1+\mathrm{C} 2-\mathrm{C} 1 \mathrm{f}$ & & \\
\hline & & $\mathrm{D}$ & $"$ & あとつぎし & & & & \\
\hline & & $\begin{array}{c}E \\
F_{1}\end{array}$ & "1" & 盖策が主 & & $=\mathbb{I I}=\mathrm{B}+\mathrm{FB} 1+\mathrm{C} 1 \quad \mathrm{f}+\mathrm{D})$ & & II) \\
\hline & & $\mathrm{FB} 2$ & その他 & 菲棌が主 & & $+E+F \mathbb{I I}$ & & \\
\hline & & $\mathrm{F}$ III & その他 & 兼垱 が 就 & & & & \\
\hline & & $\mathrm{F} \mathrm{F}$ & 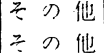 & 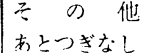 & & 木 $\mathrm{N})=\mathrm{F} F$ & & IV \\
\hline
\end{tabular}




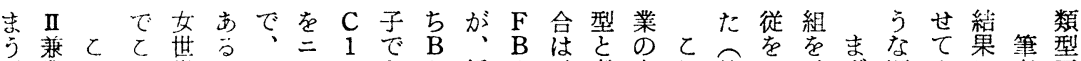

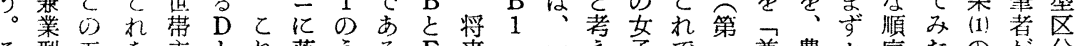
そ型五を主乞れ落うる $\mathrm{F}$ 来・同え子で一兼農也序たのが分

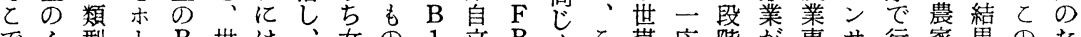
でふ型と B 世は、女の 1 立 $\mathrm{B} く こ$ 帯応隋が専サ行家果のた

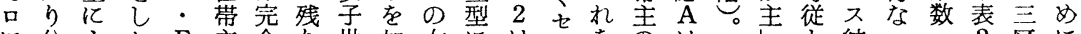
に分よた $\mathrm{F}$ 主全り世加女にはンをのは結った2区

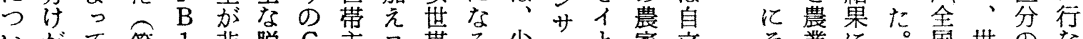
いかて第 1 非脱 C主吊る带る少ス家立そ業に。国世のな

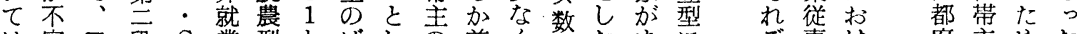

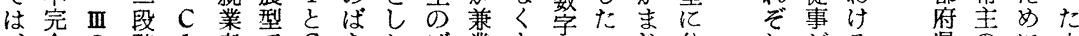

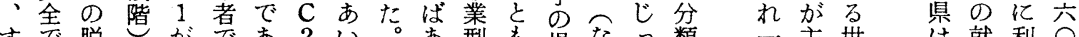

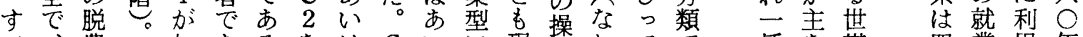
べ、農加あるをはCい現作おてで

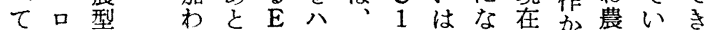
のの岕さうのとむ山てる農占業るる

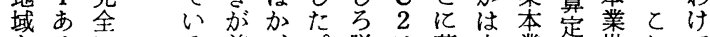
あるに方兼、。眖は落末業走机で るい区業す二農あし確者た带をあ 心は分は従では型る、定加も主のる

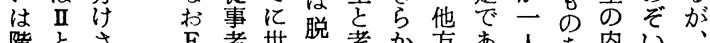

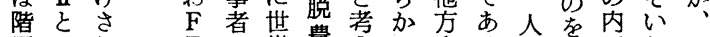
層いれ お類加分方范業うそる角女のう

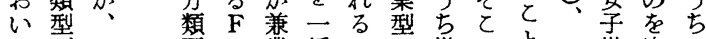

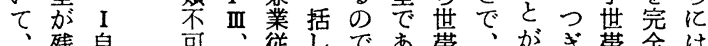
々残自立可能さ事たであ帯てが蒂全は のて型な等をて者名の加 $\mathrm{B}$ 自業 他しをの纪完の机妨る。割立本

括存带四業用年 る農圭艺䈕た 界 と業あ 1との農 方と济亦は森 任主うと業 よ芒 でうセセ っにのあぎン て、就る。节晋 の業状組業農結

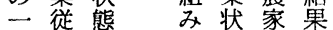
○事の加態 調 の 組 が組光查改 汪主合報算 組方图組告方 み兼せ 7 み畫法 替業恶少合出

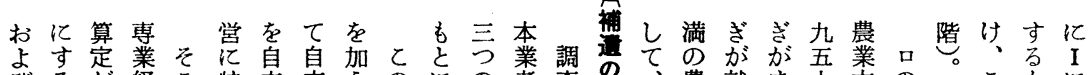

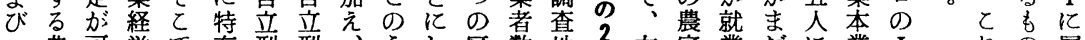
一典可営で有型型 $5 し$ 数地 2

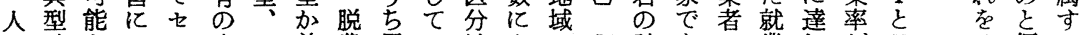

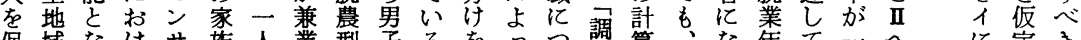

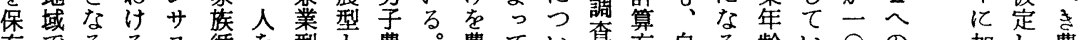
有でるるス循を型と農。農てい积自る龄い○の 加し 農

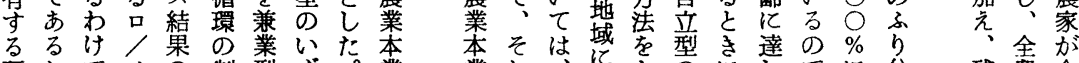

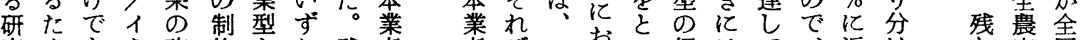

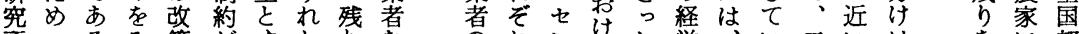
所二るみ算加すからなのれン営い心いは都

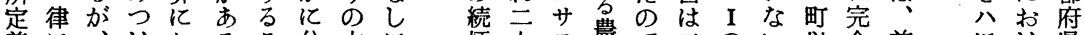
義に、けおると分本に柄人ス農で至の心以全前にけ県 亿はオ出けたとけ業、 お決のせるふる。者本 けめ值ばイ、纴業 るらは、・応る人者 專机補口机はわお方 業な調遺には考けよ一 農い植1あ妥えでび人

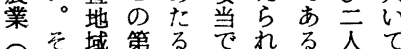

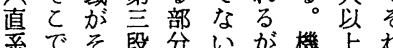

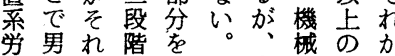
㿥男爫階算

力労机周出

㗢性已 ま兰学法上疾以すを 引異で㲊経上べの 先的農父化区家 乙分在 资累 料 乙 農 をの業
に以の家あ町自時上なに

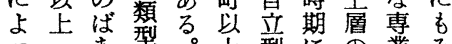
て亡あ型。㲊型にの恶み

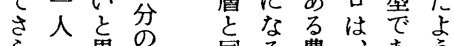
方異方同る農市方 になな方宾萣家り、に 細し 可峾 か の

類方 ま゙ 類宁農

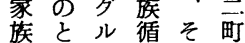
循考 1 環の以 環えプの男上 存で過子は 行さ、程 本值 な汇桨で業系 そ江来者労

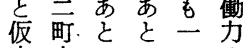
定末うう。
加る の え 乙 割 以 と 合 上 に售

b 町 口

以 $/$ 引 上 分品 け它 たイ割 第 光 合 第を存 段方在 


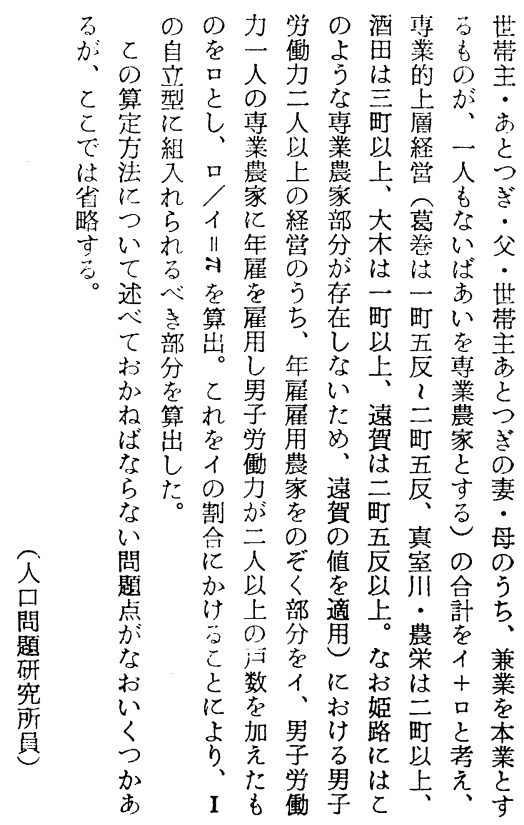

計握に.

画し研法復 等な究律雑 のが。等困 解ら全の難 決、巻諸な 策そを分都 をの通野市 示経しの問 乙済て専題 た構都門に 実造市家つ 務、のがい 家財実協て 必. 態力 読行をし技 の政正て術 書や確総。 。都に合経 市把的済

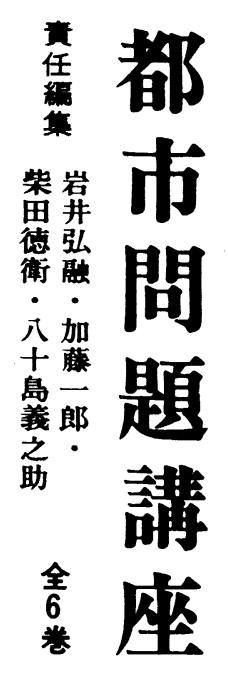

東京/神田／神保町有 斐 閣 振替/東京 370 番 
hectare of farmland.

ii. More than half of the households in type (c) own less than 0.5 hectares of farmland.

iii. Households with 0.5 to 1.5 hectares of farmland mainly belong to the (b) type household, the intermediate class.

In the intermediate class most of the heirs of farm households are gainfully employed in outside jobs, but in the future when they become heads of the household, they have to face the problem of whether to return to the farm or remain on the present job. Especially in tbe case of households owning more than 0.7 hectares the choice of whether to return to the farm or remain on the outside job will cause changes in the method of farming, because most of them now belong to type (i).

2. In spite of the rapid rate at which the labor force in farms is taking up jobs besides farming, more than one-half of the farmer's households today still belong in the low income bracket. Therefore, it is quite clear that more farmers including the heads of families and heirs will be seeking jobs besides farming, in order to relieve economic pressures. The majority of the farmers with less than 0.7 hectares will have to belong to type (c) and more than one-half of those with more than one hectare will have to belong to type (b) household. We imagine that, as a whole, the distribution will be $10 \%$ of type (a), $30 \%$ of type (b), and $60 \%$ of type (c), and, as a result, the farming population, including heads of households and their heirs will drop from the present six million to three million.

The present acute part-time trend of the farming labor forces will naturally give rise to serious problems in thel future of the farming industry of this country. The decrease in the farm labor force as it is seen today may eventually cause a decrease in farm households, but the optimistic outlook to the effect that this phenomenon will cause an enlargement of the scale of farm management and improve the mode of farming has no bearing at all. And if the present trend is allowed to continue, we have the difficult problem of having to face the possibility of the decay of the farming industry itself. The problem of low income farm households could not be dissolved just by acceleration of the part-time trend of farm householders and their heirs, but rather support must be looked for improvements in the modes of farming and rising of productivity in the family farms. 


\section{Analysis of the Trend to Part-Time Agriculture \\ by Farm Householders and their Heirs : \\ - It's Present State and Future -}

\section{Yuichi Minakawa \\ Institute of Population Problems}

In the process of a rapid economic growth since 1955, the part-time trend among farming labor forces has considerably increased. Consequently, the abandonment of agriculture by householders and their heirs, an increase in the proportion of women farmers and the aging of farming population are occurring, presenting a new and grave problem in agricultural management.

In this article, the progress of the part-time tendency is reviewed mainly through the percentage of full-time agricultural workers classified by their age and status in family. And then, farm households were classified into three types on the basis of the employment status of farm householders and their heirs. The number of farm households now in the low income bracket which, even with the help of the extra income derived from outside jobs, still have difficulty in maintaining their livelihood were also calculated.

These analyses and calculations were based on the research data of seven typical rural communities which were surveyed in 1961 and on the data of the 1960 census of agriculture and forestry in Japan.

Some important results concerning the analysis of the 1960 census data are as follows.

1. Farming households were classified into three types :

a. Households in which both the head of the family and his heir are engaged in farming only.

b. Households in which the head of the family or the heir (usually the heir) is engaged in jobs outside the farm.

c. Households in which both the head of the family and heir are engaged only in jobs other than farming.

As a whole these three types of households are equally divided, that is to say, each type comprising about one-third of the whole at present. And the distribution of these three types according to the size of farm appeared to be appoximately as follows :

i. More than half of the households in type (a) own more than one 